\title{
An overview on protecting metal anodes with alloy-type coating
}

\author{
Justine Touja, ${ }^{1.2^{*}}$ Nicolas Louvain, ${ }^{1.2}$ Lorenzo Stievano, ${ }^{1.2}$ Laure Monconduit, ${ }^{1.2}$ and Romain Berthelot ${ }^{1.2^{*}}$ \\ ${ }^{1}$ ICGM, Univ. Montpellier, CNRS, ENSCM, Montpellier, France \\ ${ }^{2}$ Réseau sur le Stockage Electrochimique de l'Energie (RS2E), CNRS, Hub de l'Energie, Amiens, France
}

\begin{abstract}
The current revival of lithium metal batteries (LMB) has been driven by both the search for high energydensity systems and the development of solid-state batteries. Lithium electrode surface engineering is crucial to limit both the dendritic growth and the electrolyte reduction. Among the various strategies to obtain protecting layers, there has been a recent growing interest in metal coatings forming alloys with lithium. Here, various strategies to coat lithium and other metal electrodes (sodium, potassium and magnesium) are reviewed and discussed with respect to their efficiency, versatility, and their possible practical transfer to the battery industry.
\end{abstract}

\section{Introduction}

Batteries have always represented a wide playground for chemists, and the game has become more intense in the last half of the twentieth century with the incredible development of rechargeable lithium-ion batteries (LIB), which was rewarded by the 2019 Nobel Prize in Chemistry. The first example of lithiumbased rechargeable battery arrived in the 70's with the work of Steele and Whittingham. ${ }^{[1,2]}$ However, both the hazardous reactivity of lithium metal towards liquid carbonate-based electrolytes and the heterogeneous plating of lithium, leading to the disordered growth of dendrites, are at the origin of the safety issues which precluded batteries containing lithium metal negative electrodes from commercialization. ${ }^{[3]}$ Several years later, the first reports on the electrochemical reversible insertion of $\mathrm{Li}^{+}$ into both graphite and the layered oxide $\mathrm{LiCOO}_{2}$ initiated the era of "rocking chair" LIB. ${ }^{[4-7]}$ They have now flooded the market by powering our ever-hungry electronic portable devices and the expanding full-electric or hybrid vehicles. However, after decades of improvements, the performance of LIB is approaching its limits in terms of energy density. In addition, safety remains a critical issue as organic liquid electrolytes 
using highly flammable solvents are still used in the commercial cells. Prospecting alternative systems with higher electrochemical performance and/or better safety warranty is now under the spotlight.

The return to lithium metal electrodes should theoretically enhance the energy performance. The revival of lithium metal batteries (LMB) is carried out today with the important goal of realizing performanceoriented all-solid-state batteries, which do not appear yet to be a mature technology. In liquid organic electrolyte-based batteries, lithium metal electrodes cannot be used as such and need surface engineering to overcome the still unsolved problem of dendrite formation. Coating the surface of lithium metal is one of the strategies that are currently widely investigated by the research community to address this issue. Protection of the electrode could be achieved by polymeric coating, ${ }^{[8-12]}$ atomic layer deposition of $\mathrm{Al}_{2} \mathrm{O}_{3}$ or $\mathrm{ZrO}_{2},{ }^{[13-16]}$ or by the formation of an inorganic layer composed with $\mathrm{Li}_{3} \mathrm{P}, \mathrm{Li}_{3} \mathrm{PO}_{4}, \mathrm{Li}_{3} \mathrm{~N}$ or LiF for example. ${ }^{[17-21]}$ In this review, we put the spotlight on alloy-type materials, which have been recently proposed to efficiently protect lithium and other metal electrodes. It has been known for quite some time that most $p$ block elements can electrochemically react at low potential with lithium to form an alloy, and have thus been extensively studied as negative electrode materials. ${ }^{[22]}$ This reaction is driven by a strong difference of electronegativity between lithium and the $p$-block element, and undergoes a conversion process as the crystallographic structure of the alloy differs from the initial $p$-block element. The electrochemically formed alloy could be also prepared by a metallurgic approach involving, for instance, high-temperature treatments or mechanochemical synthesis. The electrochemical alloying is strongly influenced by the phase diagram; however, it is interesting to point out that some compositions formed during the process are thermodynamically unstable or obtained only at very high pressure. ${ }^{[22-26]}$ Electrochemical alloying with $p$ block elements has been also widely investigated for sodium-, potassium- and magnesium-based batteries. ${ }^{[27-35]}$

Going back to electrode materials for rechargeable batteries, the alloying mechanism is different from a topotactic insertion process where lithium ions go in and out of the electrode host without substantially altering the crystallographic structure, such as graphite and layered transition metal oxides for negative and positive electrodes, respectively. The alloying process usually involves more lithium per formula unit in comparison with topotactic mechanism where the redox process is mainly linked to a transition metal. Consequently, the electrochemical alloying often lead to high specific and/or volumetric capacities. Silicon is somehow the most pertinent example: abundant on Earth, non-hazardous, it is able to electrochemically form several $\mathrm{Li}_{x} \mathrm{Si}$ alloys with lithium, especially the most lithiated $\mathrm{Li}_{15} \mathrm{Si}_{4}\left(3580 \mathrm{mAh} \mathrm{g}^{-1}\right.$ and $\left.100 \mathrm{Ah} \mathrm{cm}^{-3}\right)$ at an average potential around $0.1 \mathrm{~V} v$ s. $\mathrm{Li}^{+} / \mathrm{Li}^{\left[{ }^{[36]}\right.}$ However, important volume changes during the lithiation and delithiation process limit the cycle life. ${ }^{[36-39]}$ Significant improvements have been made through the formulation of the electrode in order to mitigate this issue, and long-life cycling has been reported for lithium- and sodium-based systems. ${ }^{[40,41]}$ Nevertheless, alloy-type elements are not mature for commercial 
rechargeable LIB, and even though silicon is under the spotlights, its use is limited to being an additive in graphite-based negative electrodes to increase the capacity. ${ }^{[37,42]}$

Although the future application of $p$-block elements as the main component of a negative electrode is not yet marketable, they could be used as coating layers to protect the metal electrode, especially by preventing the growth of lithium dendrites and/or by influencing the formation of a stable solid electrolyte interphase (SEI).

The purpose of this review is to present an exhaustive view of the different strategies of alloy-type coating that have been reported so far on lithium electrodes. Experimental protocols will be described and compared. The characteristics of the coating, as well as their effects on the electrochemical behavior of the electrode, will be also discussed in the light of advanced characterization techniques. In the current context of exploring alternative to lithium-based batteries, ${ }^{[43]}$ due to the increasing concerns regarding the sustainability of lithium sources, we will also present and discuss recent achievements of coated metallic electrodes obtained in sodium, potassium or magnesium-based batteries.

\section{Strategies for alloy-type coating on the surface of metallic electrodes}

\subsection{Chemical reduction of a salt/ionocovalent compound in solution}

The chemical reduction of a salt or ionocovalent compound $\left(\mathrm{MX}_{\mathrm{x}}\right.$, where $\mathrm{M}$ is a $p$-block metal or a semimetal and $\mathrm{X}$ a halogen) dissolved in solution is the most common way to deposit a $p$-block element (M) on the surface of lithium. The reduction of this precursor is driven by the very low redox potential of lithium $(-3.05 \mathrm{~V}$ vs. standard hydrogen electrode $(\mathrm{SHE}))$, and it is also the case for other alkali or alkaline-earth metals (-2.7, -2.9, -2.4 V vs. SHE for $\mathrm{Na}, \mathrm{K}$ and $\mathrm{Mg}$, respectively). In contact with a less reducing element, an instant reaction is expected to occur. The $p$-block cation being reduced, the halogenide will combine with lithium to form a by-product (LiX). In most cases, the as-deposited $p$-block element $M$ is highly reactive and thanks to the electronegativity difference the metal can then react with lithium to form an alloy. There are then strong similarities between the electrochemical process and a metallurgic synthesis. The overall coating process is summarized in equations 1 and 2 .

$$
\begin{aligned}
& x \mathrm{Li}+\mathrm{MX}_{x} \rightarrow \mathrm{M}+x \mathrm{LiX} \\
& y \mathrm{Li}+z \mathrm{M} \rightarrow \mathrm{Li}_{y} \mathrm{M}_{z}
\end{aligned}
$$

Through this technique, the interface obtained at the surface of the metal electrode could be seen as a composite layer gathering the metal, an alloy (often) and a by-product. Similarly to halogenides, also more sophisticated TFSI-containing compounds with general formula $\mathrm{M}\left(\mathrm{TFSI}{ }_{\mathrm{n}}\right.$ have been considered (vide infra, Tables 1 et 2). 
In 2017, the groups of Nazar and Archer firstly proposed this strategy to stabilize the lithium metal anode. Liang et al. reviewed solutions of different chlorides salts $\left(\mathrm{AsCl}_{3}, \mathrm{InCl}_{3}, \mathrm{ZrCl}_{4}, \mathrm{BiCl}_{3}\right)$ dissolved in tetrahydrofuran (THF). ${ }^{[44]}$ After a short immersion of $20 \mathrm{~s}$, the shiny polished surface of lithium turns dark and the formation of a thin composite layer combining either the reduced metal (As, In, $\mathrm{Zr}, \mathrm{Bi}$ ) and/or an alloy ( $\mathrm{Li}_{3} \mathrm{As}, \mathrm{Li}_{13} \mathrm{In}_{3}, \mathrm{LiZr}, \mathrm{Li}_{3} \mathrm{Bi}$, respectively) was evidenced and characterized by $\mathrm{X}$-ray diffraction (XRD), scanning electron microscopy coupled with energy-dispersive X-ray spectroscopy (SEM-EDX) and X-ray photoemission spectroscopy (XPS). In parallel, Choudhury et al. highlighted another indium salt - In(TFSI) 3 to create a $\ln / \mathrm{Li}_{x} \mathrm{In}_{y}$ alloy composite protection on top of lithium. ${ }^{[45]}$ Later on, the same groups either reviewed all indium halides $\left(\ln X_{3}, X=F, C l, B r, I\right)^{[46]}$ or applied the same protocol to protect sodium metal with $\mathrm{Sn}(\mathrm{TFSI})_{2}$ solutions. ${ }^{[4]}$ Following this series of pioneering works, additional studies benchmarked other salts and solutions, investigated other coating protocols instead of electrode dipping for a better control of the coating (Table 1), and also extended the approach to sodium and even more recently potassium and magnesium electrodes (Table 2).

Suitable characterization techniques to evaluate the coating are logically SEM and XPS. Cross-section SEM pictures provide a good morphological description of the coating. EDX mapping is used to evaluate the overlapping yield, estimate the homogeneity of the coating and measure the thickness of the layer (Figure 1). In most cases, the latter is between 2 and $10 \mu \mathrm{m}$ (Tables 1 and 2). XPS offers a surface-only characterization, but allows the identification of several species based on their binding energy. Thanks to destructive sputtering treatments, it is also possible to get information on the homogeneity of the artificial interface (Figure 2).
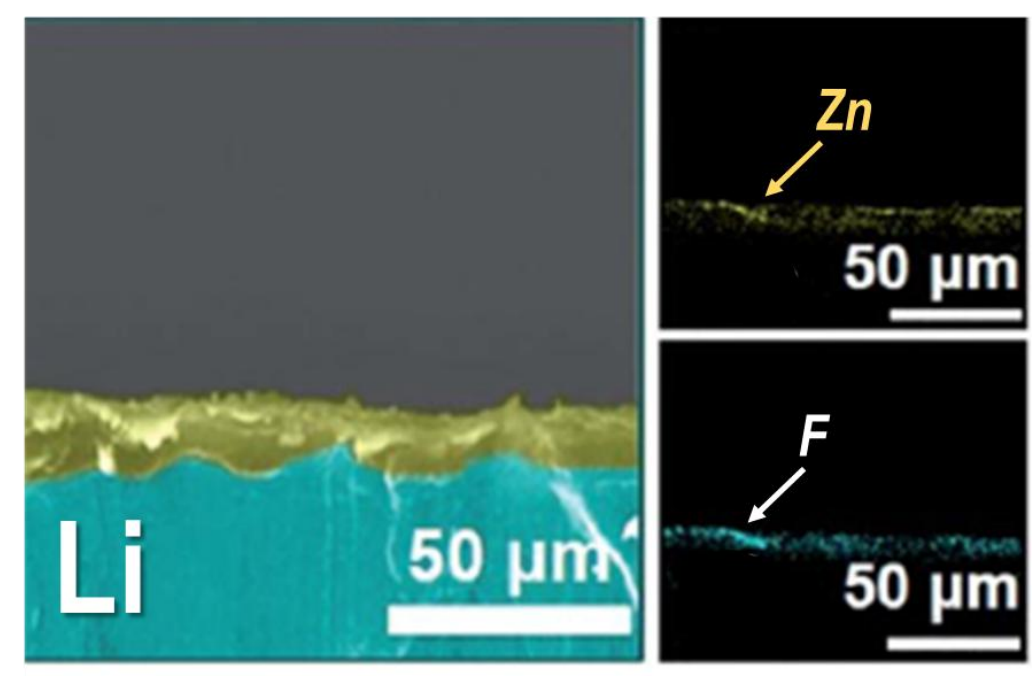

Figure 1. Example of cross-section SEM images for charactering the coating. Here, lithium electrode is protected by immersion in $\mathrm{ZnF}_{2} /(D O L: D M E)$ dispersion. The EDX mapping on the right confirm the deposition of zinc, as well as the presence of fluorine in the by-product LiF. Adapted with permission from Ref. [50], Copyright 2019 Royal Society of Chemistry. 
a)

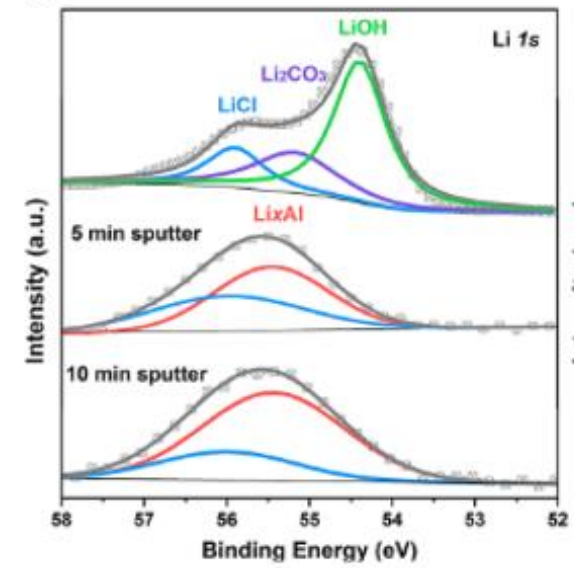

b)

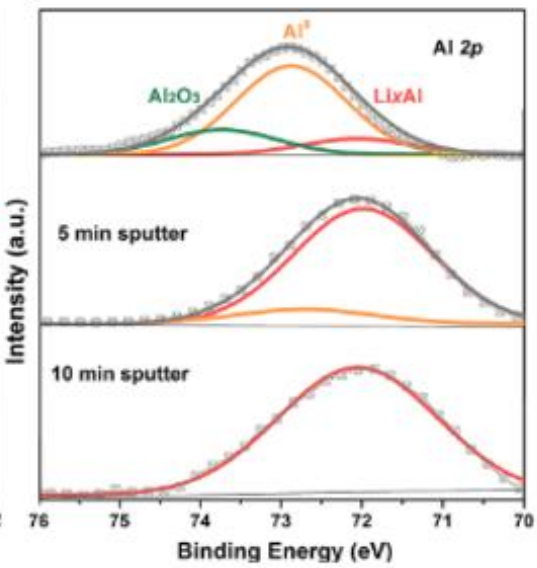

c)

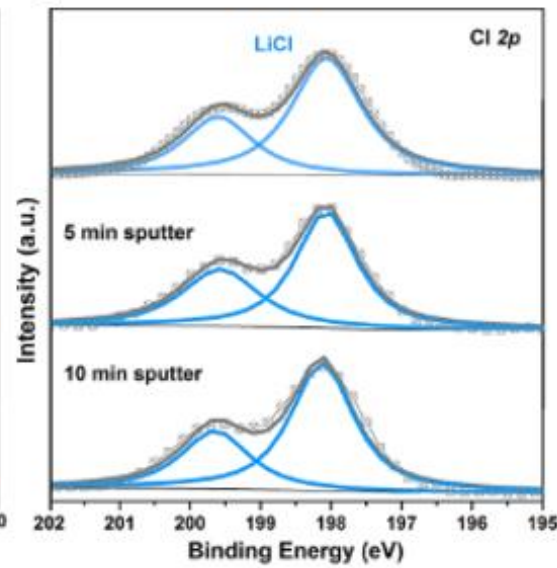

Figure 2. XPS analysis of the lithium electrode treated with $\mathrm{AlCl}_{3}-\mathrm{THF}$ solution before and after Ar sputtering: (a) Li 1s, (b) Al $2 p$ and (c) Cl $2 p$ spectra. Analysis performed after argon sputtering suggests a uniform distribution of $\mathrm{LiCl}$ in the whole coating layer. Reproduced with permission from Ref. [49]. Copyright 2020, Elsevier

When it comes to electrochemical analysis, the efficiency of the coating strongly depends on its thickness and uniformity, and thus on the chemical bond strength between the alkali and its neighboring atoms in the alloy or the salt. For a given coating solution, these characteristics can be tuned by optimizing the amount of metal salt or ionocovalent compound $\mathrm{MX}_{\mathrm{x}}$ (concentration and ratio between the volume of the solution of $\mathrm{MX}_{\mathrm{x}}$ and the surface to coat) and the time of contact between the electrode and the solution. Most of the published works to date reported the coating protocol and the corresponding characterization for the most efficient coating with respect to the electrochemical behavior. To the best of our knowledge, only very few examples of a systematic investigation of the influence of the coating parameters exist. It is thus difficult to draw conclusions about the key parameters that must be controlled to obtain an efficient coating. As an example, Chen et al. protected lithium metal with a Sb-based lithiophilic interface by immersing the electrode in $\mathrm{Sbl}_{3} / \mathrm{THF}$ solutions with different concentration. At $25 \mathrm{mM}$ or below, the formation of a compact and dense layer on lithium was not possible, whereas a rough surface including some cracks was obtained with concentration exceeding $100 \mathrm{mM} \cdot{ }^{[48]}$ In parallel to solution concentration, the time of reaction is another key parameter. However, the reduction of the reactant and the alloying reaction seem to occur quite rapidly, and therefore long time treatments do not appear to be necessary. As shown in Tables 1 and 2, the coating treatments are relatively short. 


\begin{tabular}{|c|c|c|c|c|}
\hline $\mathrm{MX}_{\mathrm{x}}$ solution & Protocol & Layer composition & Layer thickness & Ref. \\
\hline $\mathrm{InCl}_{3} / \mathrm{THF}(0.167 \mathrm{M})$ & \multirow[t]{4}{*}{ immersion (20s) } & $\mathrm{Li}_{13} \mathrm{In}_{3}+\mathrm{LiCl}$ & \multirow[t]{4}{*}{$<10 \mu \mathrm{m}$} & \multirow[t]{4}{*}{ [44] } \\
\hline $\mathrm{AsCl}_{3} / \mathrm{THF}(0.167 \mathrm{M})$ & & $\mathrm{Li}_{3} \mathrm{As}+\mathrm{LiCl}$ & & \\
\hline $\mathrm{ZnCl}_{2} / \mathrm{THF}(0.167 \mathrm{M})$ & & $\mathrm{LiZn}+\mathrm{LiCl}$ & & \\
\hline $\mathrm{BiCl}_{3} / \mathrm{THF}(0.167 \mathrm{M})$ & & $\mathrm{Li}_{3} \mathrm{Bi}+\mathrm{LiCl}$ & & \\
\hline \multicolumn{2}{|c|}{$\ln (\mathrm{TFSI})_{3}$ additive in $\mathrm{LiPF}_{6} / \mathrm{EC}: \mathrm{DMC}$} & $\ln +\ln _{x} \mathrm{Li}_{y}$ & $\mathrm{n} / \mathrm{a}$ & [45] \\
\hline \multicolumn{2}{|c|}{$\begin{array}{l}\operatorname{InF}_{3}(\mathrm{X}=\mathrm{F}, \mathrm{Cl}, \mathrm{Br}, \mathrm{I}) \text { additive in } \mathrm{LiPF}_{6} / \mathrm{EC}: \mathrm{DMC} \\
\text { Other tested halides } \operatorname{In} \mathrm{X}_{3}(\mathrm{X}=\mathrm{Cl}, \mathrm{Br}, \mathrm{I})\end{array}$} & $\ln +\mathrm{Li}_{15} \ln _{3}+\mathrm{LiF}$ & $1 \mu \mathrm{m}$ & [46] \\
\hline $\begin{array}{l}\text { SnTFSI EC:DMC(1- } \\
\text { 100mM) }\end{array}$ & $\begin{array}{c}100 \mu \mathrm{L} \text { dropped, } 30 \mathrm{~min} . \\
\text { reaction }\end{array}$ & $\mathrm{Sn}+\mathrm{Li}_{5} \mathrm{Sn}_{2}$ & $\begin{array}{l}500 \mathrm{~nm} \text { or } \\
2 \mu \mathrm{m}\end{array}$ & [47] \\
\hline $\begin{array}{l}0.05 \mathrm{~mol} \mathrm{~kg}^{-1} \\
\mathrm{AlCl}_{3} / \mathrm{THF}\end{array}$ & $\begin{array}{l}20 \mu \mathrm{L} \mathrm{cm}^{-2} \text { dropped on } \\
\text { surface }\end{array}$ & $\mathrm{Li}_{x} \mathrm{Al}+\mathrm{LiCl}$ & $2.5 \mu \mathrm{m}$ & [49] \\
\hline $\begin{array}{c}\mathrm{MF}_{\mathrm{x}} \text { nanoparticles } \\
(\mathrm{M}=\mathrm{Zn}, \mathrm{Ca}, \mathrm{Mg}, \mathrm{Al}) \text { in } \\
\mathrm{DOL} / \mathrm{DME}(90 \mathrm{mM})\end{array}$ & Immersion & $\mathrm{Li}-\mathrm{M}+\mathrm{LiF}$ & $5-10 \mu \mathrm{m}$ & [50] \\
\hline ZnTFS/THF (0.1M) & $20 \mathrm{~s}$ immersion & LiZn & $12.5 \mu \mathrm{m}$ & [51] \\
\hline $\mathrm{Sbl}_{3} / \mathrm{THF}(50 \mathrm{mM})$ & $\begin{array}{c}3 \mathrm{~min} \text { immersion of } \varnothing 12 \mathrm{~mm} \\
\text { disc in } 5 \mathrm{~mL}\end{array}$ & $\mathrm{Sb}+\mathrm{Li}_{3} \mathrm{Sb}$ (amorp.) & $2.5 \mu \mathrm{m}$ & [52] \\
\hline $\begin{array}{l}\mathrm{SnF}_{2} \text { additive (1 - } \\
3 \mathrm{wt} \% \text { ) in } \\
\mathrm{LiPF}_{6} / \mathrm{EC}: \mathrm{DEC}(1 \mathrm{M})\end{array}$ & $\begin{array}{c}30 \mu \mathrm{L} \text { dropped on surface }(\varnothing \\
15.6 \mathrm{~mm})\end{array}$ & $\mathrm{Sn}+\mathrm{Li}_{5} \mathrm{Sn}_{2}+\mathrm{LiF}$ & 10 to $55 \mu \mathrm{m}$ & [53] \\
\hline $\mathrm{AlCl}_{3} / \mathrm{THF}(0.3)$ & 2 min immersion & $\mathrm{LiAl}+\mathrm{LiCl}$ & $2 \mu \mathrm{m}$ & [54] \\
\hline $50 \mathrm{mM}$ of $\mathrm{Mg}$ additive & \multirow{6}{*}{$\begin{array}{l}\text { Additives in } \mathrm{LiPF}_{6} / \mathrm{EC}: \mathrm{DEC} \\
\text { electrolyte }\end{array}$} & $\mathrm{Mg}$ & $7 \mu \mathrm{m}$ & \multirow[t]{6}{*}{ [55] } \\
\hline $50 \mathrm{mM}$ of $\mathrm{Zn}$ additive & & $L i Z n+Z n$ & $8 \mu \mathrm{m}$ & \\
\hline $50 \mathrm{mM}$ of $\mathrm{Au}$ additive & & $\mathrm{LiAu}+\mathrm{Au}$ & $\mathrm{n} / \mathrm{a}$ & \\
\hline $50 \mathrm{mM}$ of $\mathrm{Al}$ additive & & Al & $\mathrm{n} / \mathrm{a}$ & \\
\hline $50 \mathrm{mM}$ of $\mathrm{Fe}$ additive & & $\mathrm{Fe}$ & $10 \mu \mathrm{m}$ & \\
\hline $50 \mathrm{mM}$ of $\mathrm{Cu}$ additive & & $\mathrm{Cu}$ & $\mathrm{n} / \mathrm{a}$ & \\
\hline $\begin{array}{c}\mathrm{AgNO}_{3} \text { in } \\
\text { LiTFSI/DOL:DME }\end{array}$ & $\begin{array}{l}120 \mu \mathrm{L} \text { dropped on the } \\
\text { surface }\end{array}$ & $\mathrm{Ag}_{x} \mathrm{Li}_{\mathrm{y}}+\mathrm{Li}_{2} \mathrm{O}+\mathrm{LiF}$ & $120 \mu \mathrm{m}$ & [56] \\
\hline $\begin{array}{l}\text { Ga nanoparticles in } \\
\text { DOL }\end{array}$ & $\begin{array}{l}\text { Solution dropped on the } \\
\text { surface }\end{array}$ & $\mathrm{Li}_{2} \mathrm{Ga}$ & $10 \mu \mathrm{m}$ & [57] \\
\hline
\end{tabular}

Table 1. Coating protocols and characteristics of lithium electrode 


\begin{tabular}{|c|c|c|c|c|c|}
\hline Electrode & $M X_{x}$ solution & Protocol & Layer composition & Layer thickness & Ref. \\
\hline \multirow[t]{4}{*}{$\mathrm{Na}$} & $\begin{array}{l}\text { SnTFSI EC:DMC } \\
(1-100 \mathrm{mM})\end{array}$ & $\begin{array}{l}100 \mu \mathrm{L} \text { dropped, } \\
30 \mathrm{~min} \text {. reaction }\end{array}$ & $\mathrm{Na}_{9} \mathrm{Sn}_{4}, \mathrm{Na}_{15} \mathrm{Sn}_{4}$ & $500 n m-2 \mu m$ & 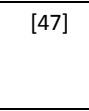 \\
\hline & \multicolumn{2}{|c|}{$\begin{array}{c}\mathrm{SnCl}_{2} \text { additive in } \mathrm{NaClO}_{4} / \mathrm{EC}: \mathrm{PC} \mathrm{(1M)} \\
\text { electrolyte }\end{array}$} & $\mathrm{Sn}, \mathrm{Na}_{15} \mathrm{Sn}_{4}, \mathrm{NaCl}$ & $38 \mu \mathrm{m}$ & [58] \\
\hline & $\begin{array}{c}\mathrm{Bi}\left(\mathrm{SO}_{3} \mathrm{CF}_{3}\right)_{3} / \mathrm{DME} \\
(10 \mathrm{mM})\end{array}$ & $\begin{array}{l}40 \mu \mathrm{L} \text { dropping on } \\
\text { surface }\end{array}$ & $\mathrm{Bi}$ & $10 \mu \mathrm{m}$ & [59] \\
\hline & $\begin{array}{l}\mathrm{SnCl}_{2} \text { in diglyme } \\
\text { or liquid } \mathrm{SnCl}_{4}\end{array}$ & $\begin{array}{c}4 \mu \mathrm{L} \text { of } \mathrm{SnCl}_{2} / \mathrm{DGM} \\
\text { or } 2 \mu \mathrm{L} \text { of liquid } \\
\mathrm{SnCl}_{4}\end{array}$ & $\mathrm{Na}_{15} \mathrm{Sn}_{4}, \mathrm{NaCl}$ & $3.4 \mu \mathrm{m}$ & [60] \\
\hline \multirow[t]{3}{*}{$\mathrm{Mg}$} & $\begin{array}{l}\mathrm{SnCl}_{2} / \mathrm{DME}(50- \\
150 \mathrm{mM})\end{array}$ & $\begin{array}{l}100 \mu \mathrm{L} \text { dropping on } \\
\text { surface }(\varnothing 12 \mathrm{~mm})\end{array}$ & $\mathrm{Sn}, \mathrm{Mg}_{2} \mathrm{Sn}$ & $2 \mu \mathrm{m}$ & [61] \\
\hline & \multicolumn{2}{|c|}{$\mathrm{GeCl}_{4}$ in $\mathrm{Mg}(\mathrm{TFSI})_{2} / \mathrm{DME}$ electrolyte } & $\mathrm{Ge}$ & $\sim 6 \mu \mathrm{m}$ & [62] \\
\hline & $\begin{array}{l}0.1 \mathrm{M} \mathrm{BiCl}_{3} \\
\text { solution }\end{array}$ & $2.5 \mathrm{~h}$ immersion & $\mathrm{Mg}_{3} \mathrm{Bi}_{2}$ & $70 \mu \mathrm{m}$ & $\begin{array}{l}63] \\
\end{array}$ \\
\hline
\end{tabular}

Table 2. Coating protocols and characteristics of $\mathrm{Na}$ and $\mathrm{Mg}$ metal electrodes

\subsection{Other techniques of coating}

Besides solution coating, alternative strategies to create an alloy layer on the metal electrode have been proposed. These strategies might be less transferrable to industry production, but they nevertheless enable working with other alloy-type elements. On top of that, some of them allow the formation of an artificial interface free of by-product. Some of these alternative protocols are described hereafter and schematized in Figure 3.

Solid-gas reaction is an elegant approach to modify the surface of a metal electrode. She and coworkers reported the protection of sodium with tin-based coating by the action of vapors of tin tetrachloride $\left(\mathrm{SnCl}_{4}\right)$. After only $10 \mathrm{~s}$, a $6 \mu \mathrm{m}$ layer of a Na-Sn alloy was identified by both XRD and cross-section SEM. ${ }^{[64]}$ In a similar manner, Liao and coworkers exposed a lithium disk to a $\mathrm{GeCl}_{4} / \mathrm{THF}$ vapor for several minutes to create a thin $1.5 \mu \mathrm{m}$ protective layer of germanium. ${ }^{[65]}$

Chen et al. grew a uniform and ultrathin $(40 \mathrm{~nm})$ bismuth film directly on the surface of a lithium foil by evaporating high-purity $\mathrm{Bi}$ metal using a large-orifice pocket electron-beam evaporator. ${ }^{[66]}$ Another technique used by Xia et al. is the thermal evaporation of Sn metal at low pressure $\left(\sim 2.10^{-3} \mathrm{~Pa}\right) .{ }^{[67]} \mathrm{In}$ this work, the Sn metal source was placed in a crucible heater source, and the produced Sn vapor deposited onto the Li foil with a deposition rate of $0.5 \AA \mathrm{s}^{-1}$, leading to the formation of $\mathrm{Li}_{5} \mathrm{Sn}_{2}$ as evidenced by XRD.

Alternatively, Sun and coworkers prepared a thin indium foil $(700 \mathrm{~nm})$ by a simple rolling method owing to the high ductility of the metal, and then covered a lithium foil by pressure to ensure a good contact between the two metals. The alloying reaction proceeded in few seconds and a $2 \mu \mathrm{m}$ alloy interface of $\mathrm{Li}_{13} \mathrm{In}_{3}$ was then evidenced by XRD and cross-section SEM. ${ }^{[68]}$ 
Surprisingly, there are only very few examples of coating with silicon although the latter exhibits interesting electrochemical behavior in LIB. Very recently, Xu et al. simply laminated an etched thin Si membrane onto a lithium foil and succeeded in converting the top part of the membrane into $\mathrm{Li}_{x} \mathrm{Si}$ alloy. ${ }^{[69]}$

He and Ding shed light on the amalgam process with mercury to protect either lithium, sodium or potassium electrodes. By directly spreading $\mathrm{Hg}$ droplets on Li surface, the spontaneous reaction enables the formation in few minutes of a 5-10 $\mathrm{m}$ thick composite layer containing $\mathrm{LiHg}_{3}, \mathrm{LiHg}$ and $\mathrm{Li}_{3} \mathrm{Hg}$. Logically, the coating is characterized by a concentration gradient, with the Hg-rich alloy mainly concentrated at the external surface, whereas $\mathrm{LiHg}$ and $\mathrm{Li}_{3} \mathrm{Hg}$ are preferentially formed close to the interface with lithium metal. ${ }^{[70]}$ With the potassium electrode, the same protocol leads to a thicker coating $(30 \mu \mathrm{m})$ of $\mathrm{K}_{7} \mathrm{Hg}_{31}$ and $\mathrm{K}_{2} \mathrm{Hg}_{7} \cdot{ }^{[71]}$ Because of the low melting temperature of the $\mathrm{Na}$-rich $\mathrm{Na}-\mathrm{Hg}$ amalgams, a quasi-liquid state is obtained when mercury drops are spread over the sodium surface, and the thermodynamically favorable process generates violent alloying reactions inducing a non-uniform coating. For a better control of the coating, $\mathrm{Hg}$-rich alloys were firstly prepared by dissolving sodium in mercury. Starting from $\mathrm{Na}_{0.1} \mathrm{Hg}_{0.9}$, the viscosity was suitable for dropping/spreading the mixture on the Na surface for a final coating around $100 \mu \mathrm{m} .^{[72]}$.
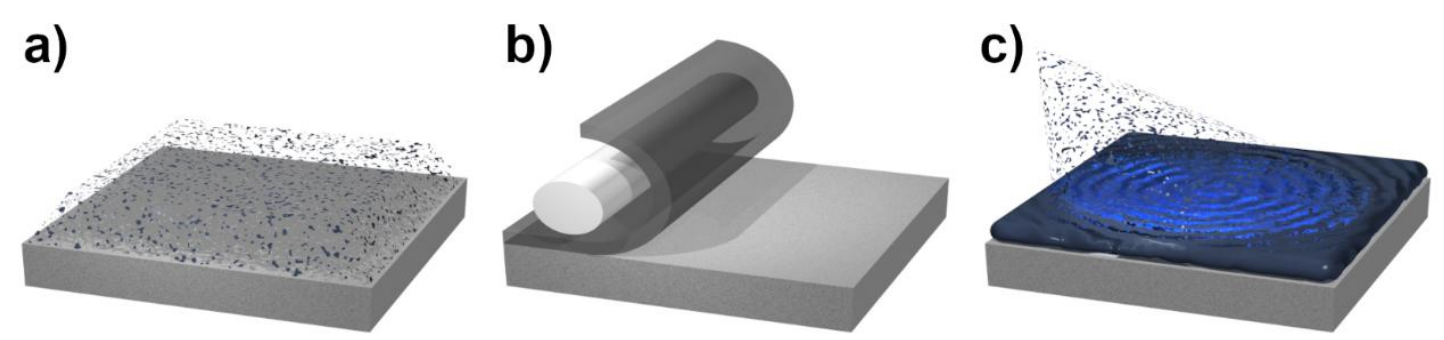

Figure 3. Schematic illustrations of other protocols of alloy-type coating. (a) Solid-gas reaction, (b) membrane lamination and (c) amalgam by drop-spreading

\section{Coating influence on the electrochemical behavior: metal plating, dendritic growth and SEI}

As mentioned earlier, in the 70 's the production of the first generation of lithium-metal batteries ( $\left.\mathrm{Li} / \mathrm{TiS}_{2}\right)$ was stopped because of safety concerns. Indeed, during the charge of the batteries, lithium preferentially deposits on specific areas of the metallic electrode surface, involving upon cycling the formation of protrusions usually named dendrites. The dendritic behavior is usually explained by the space charge model and the non-uniformity of the surface. ${ }^{[73]}$ The space charge model suggests that the dendrite growth is the result of the emergence of a concentration gradient between the electrodes upon polarization of the cell. ${ }^{[74,75]}$ Lithium plating, in fact, induces a drastic modification of the ionic concentration near the cathode. Above a critical current density J* and from a time $\tau$, also known as Sand's time, the anionic concentration 
becomes negligible, because all the anions diffuse at the anode vicinity, creating a positive space charge at the cathode side. This accelerates the Li electroplating on the cathode and the $\mathrm{Li}^{+}$concentration decreases. Above a maximal value of the electric field created by this phenomenon, the cation concentration reaches zero and the dendrites begin to grow. ${ }^{[76]}$ However, dendritic growth might occur also at current densities lower than J*. ${ }^{[75]}$ Indeed, inhomogeneity of the electrode surface, including that of the formed SEI, induce the presence of defects or conductive species, which will influence the global conductivity of the interphase and may cause high current densities on these areas and consequently promote the growth of dendrites.

Hence the use of protective layers as artificial SEI can improve the surface condition of the electrode and reduce the parasitic reactions between the electrode and the electrolyte. ${ }^{[18]}$ The surface being more homogeneous, the current density is the same on the overall surface leading to a uniform deposition of the metal and then preventing or delaying the formation of dendrites.

Reducing the formation and the growth of dendrites occurring during lithium plating is one of the main issues to be addressed in the renewed interest for LMB: it produces an increase of the exposed metal surface, promotes continuous electrolyte decomposition, and increases the SEI layer thickness. Another important effect is that during the stripping process, even though lithium is preferentially removed from the dendrites, some Li becomes electrochemically inactive, forming "dead" particles which are no more able to participate to the reaction. ${ }^{[77]}$ These phenomena result in continuous lithium consumption and poor coulombic efficiencies. Last but not least, dendrites can grow upon cycling through the separator reaching the positive electrode and short-circuit the battery leading to fire hazards. The dendritic growth has been intensively investigated in the case of lithium metal electrodes, but it also occurs for sodium, potassium and magnesium, which are gaining attention in the context of emerging post-lithium storage systems. ${ }^{[78-82]}$

Protective layers on the surface of the metallic electrodes seem to decrease the number of defects and homogenize the surface, somehow controlling this specific dendrite growth. In several studies, operando optical microscopy was used to follow the metal deposition on the electrode. For example, Liang et al. showed that coating the lithium electrode by indium enables a smooth deposition of lithium without dendrites or electrode pulverization for more than 200 cycles at $2 \mathrm{~mA} \mathrm{~cm}^{-2}$ with an areal capacity of $2 \mathrm{~mA} \mathrm{~h} \mathrm{~cm}^{-2}$ (Fig. 4a). In contrast, lithium protrusions start to appear on the unprotected Li electrode after about a hundred cycles and after 185 cycles obvious dendrites are observed. ${ }^{[44]}$ At the same cycling conditions, Ma et al. compare the sodium deposition on Bi-protected Na or on bare Na. After only 60 min, the latter shows uneven surface morphology with Na dendrites, whereas the surface of the protected electrode remains smooth and compact (Fig. 4b). ${ }^{[59]}$ With mercury addition, the amalgam-protected electrodes clearly exhibit better cycling performance upon cycling, with a reduction of dendrite nucleation and growth. For example, while $\mathrm{K}$ tree-like dendrites appear immediately after applying a current density of $0.5 \mathrm{~mA} \mathrm{~cm}^{-2}$, the Hg-protected electrode exhibits a dendrite-free morphology after $40 \mathrm{~s}$ (Fig. 4c). Further measurement revealed a dendrite-free electrode even after $1 \mathrm{~h}$ of plating. ${ }^{[71]}$ 
a)

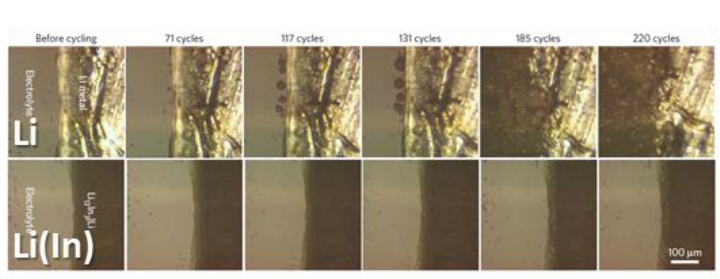

b)

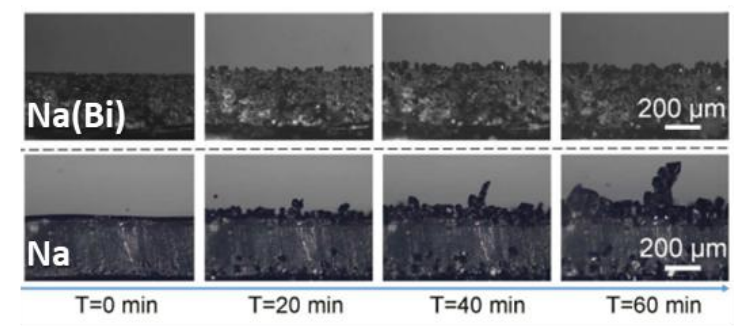

c)
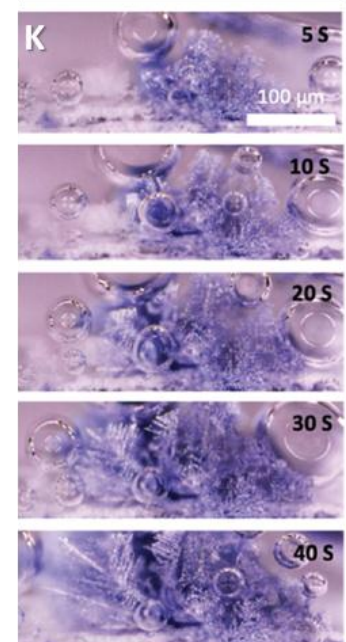

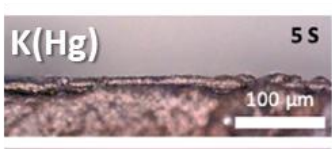

$10 \mathrm{~S}$

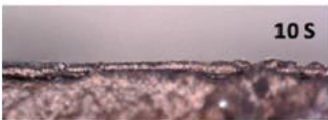

205

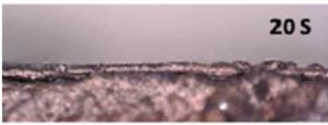

$30 \mathrm{~S}$

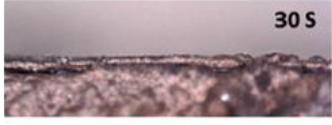

$40 \mathrm{~S}$

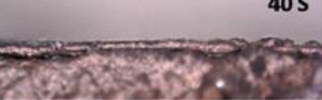

Figure 4. Examples of operando optical microscopy showing how the coating can maintain the electrode integrity by preventing dendritic growth. Cross-section images obtained during plating/stripping of (a) $\mathrm{Li}$ and In-coated Li (with LiTFSI/DOL:DME at $2 \mathrm{~mA} \mathrm{~h} \mathrm{~cm}{ }^{-2}$ ), (b) $\mathrm{Na}$ and Bi-coated $\mathrm{Na}\left(\mathrm{NaSO}_{3} \mathrm{CF}_{3} /\right.$ diglyme at

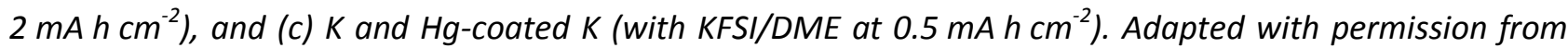
Refs. [44], [59] and [71]. Copyright 2017 Springer Nature, 2019 Wiley-VCH GmbH and 2020 Royal Society of Chemistry, respectively.

Besides optical characterizations which clearly pictures the influence of coatings on the formation of dendrites on the macroscopic scale, the long-term electrochemical behavior of metal electrodes is usually studied via plating/stripping experiments in symmetric cells, where lithium is plated and stripped alternatively on both electrodes of a 2-electrode cell. The electrochemical process appears more stable for a significantly longer time with coated electrodes, with polarization values that barely increase upon cycling. For example, Choudhury et al. made an indium coating on the lithium surface by simply adding the $\operatorname{In}(\text { TFSI })_{3}$ salt into the LiTFSI $(1 \mathrm{M})+\mathrm{PC}$ electrolyte as an additive. ${ }^{[83]}$ The comparison of the Li plating/stripping of the cell with bare lithium and the one with the protected electrodes shows clearly an improved performance for the latter one. With a current density of $1 \mathrm{~mA} \mathrm{~cm}^{-2}$, the cell with protected electrodes gives a stable overpotential of $0.1 \mathrm{~V}$ for at least $200 \mathrm{~h}$ whereas the polarization of the cell increases after 30 cycles for the other one. The experience was extended to the commercial LP30 electrolyte which also produce a stable polarization for $200 \mathrm{~h}$ whereas the electrochemical cells with the uncoated electrodes show instabilities after $100 \mathrm{~h}$. The $\mathrm{Zn}$-coated lithium electrode, proposed by Lin et al., also improved the stability of the Li plating/stripping with 1M LiTFSI in DOL/DME electrolyte at 2 and $4 \mathrm{~mA} \mathrm{~cm}^{-2}$, compared to bare Li (Fig. 5a).

Kumar et al. studied the plating/stripping behavior of $\mathrm{Na}$ electrodes protected with a Sn-based coating, which show a high stable overpotential of $0.2 \mathrm{~V}$ for more than 600 cycles at $2 \mathrm{~mA} \mathrm{~cm}^{-2}$ (Fig. 5b). ${ }^{[64]}$ This 
artificial interphase proved its efficiency even at high current densities ( 5 and $7 \mathrm{~mA} \mathrm{~cm}^{-2}$ ) since the polarization is quite stable for more than 100 cycles. Table 3 summarizes the long-term stability for plating/stripping of the studied alloy protection layers. Overall, whichever the electrode protection, the plating/stripping behavior is improved with a lower polarization, a higher stability and longer cycle life compared to bare alkali metal.
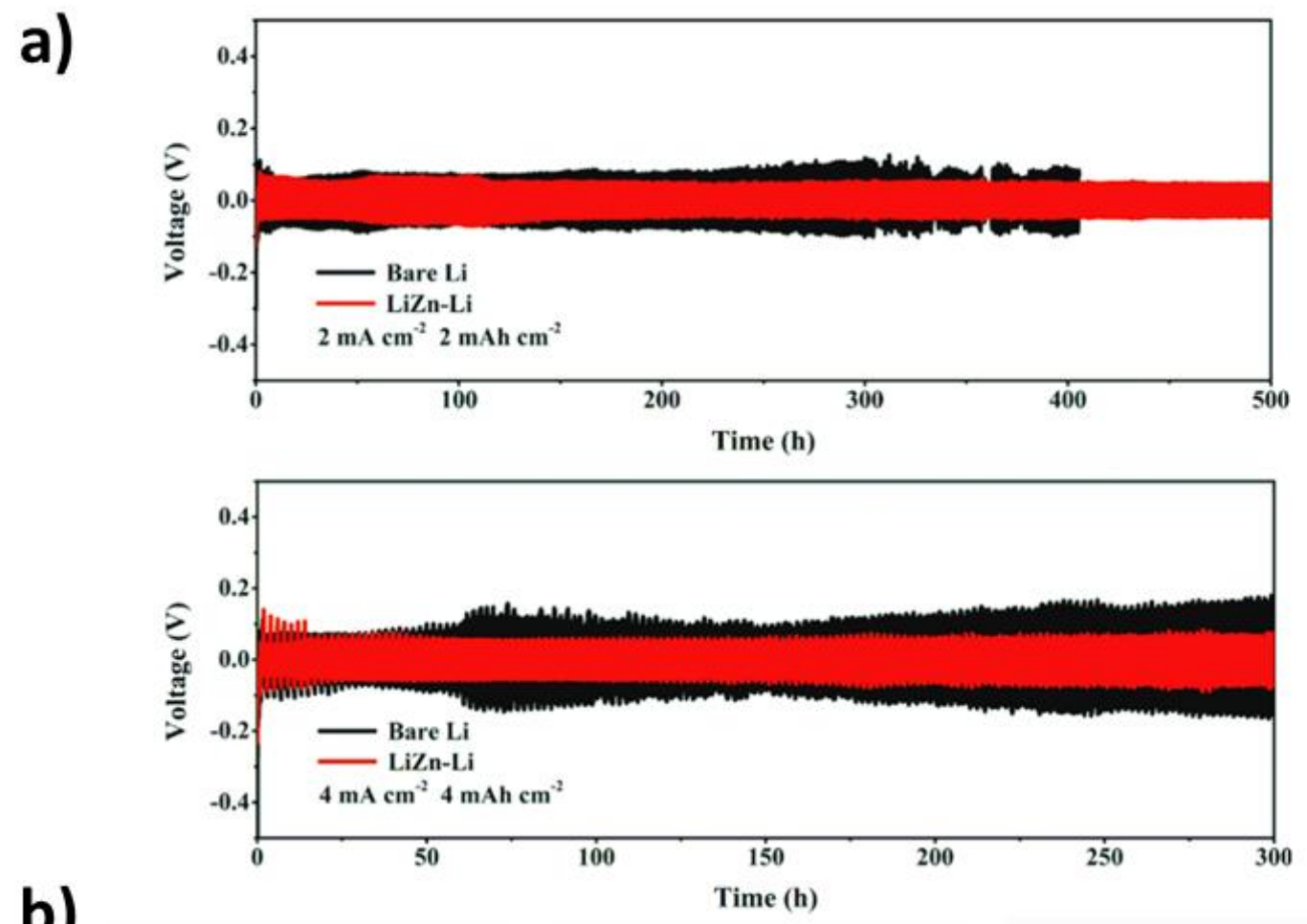

b)
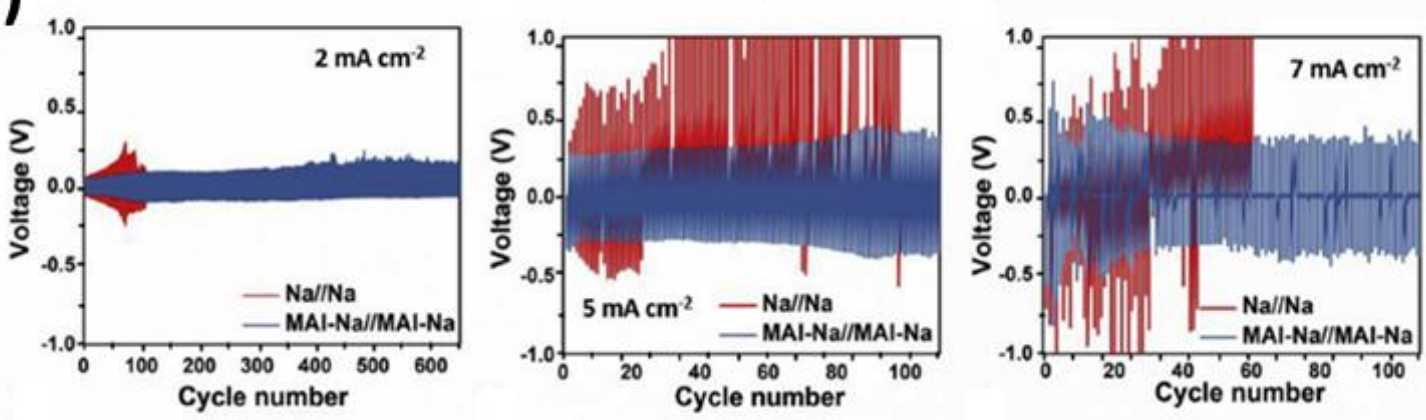

Figure 5. Examples of plating/stripping tests at various current densities in symmetric cells showing lower polarization and extended cycling process, for (a) Li and In-coated Li and for (b) Na and Sn-coated Na. Adapted with permission from Refs. [51] and [64]. Copyright 2019 Elsevier and 2020 Elsevier, respectively.

Recently, Xu et al. suggested that different protective mechanisms stabilise the alkali surface depending on the solubility of the metal $M$ used for the coating. ${ }^{[55]}$ Metals highly soluble in Li allow an easy stripping from the surface layer since the binding energy is low. At the same time, lithium would diffuse from the metal electrode reforming the surface alloy. Those with a low solubility, on the contrary, would create 
highly stable alloys with higher binding energy. In this case, more energy is needed to strip lithium, explaining the higher overpotentials observed during stripping. During plating, on the contrary, the low solubility would preferentially lead to the separate plating of lithium metal on top of the protecting layer instead of reforming a surface lithium alloy. In conclusion, the more soluble is the metal in lithium, the smoother will be the plating (Fig. 6). A previous report showed that as $\mathrm{Mg}$ and $\mathrm{Ag}$ are highly soluble in Li, whereas $\mathrm{S} n$ is not. ${ }^{[84]}$ The results in Table 3 confirm that, in most cases, the alloys with highly soluble metals in $\mathrm{Li}$ ( $\mathrm{Mg}$ or $\mathrm{Ag}$ ) show lower overpotentials than those measured with metals that are not soluble in $\mathrm{Li}$ (Fe, $\mathrm{Cu}, \mathrm{Sn})$.

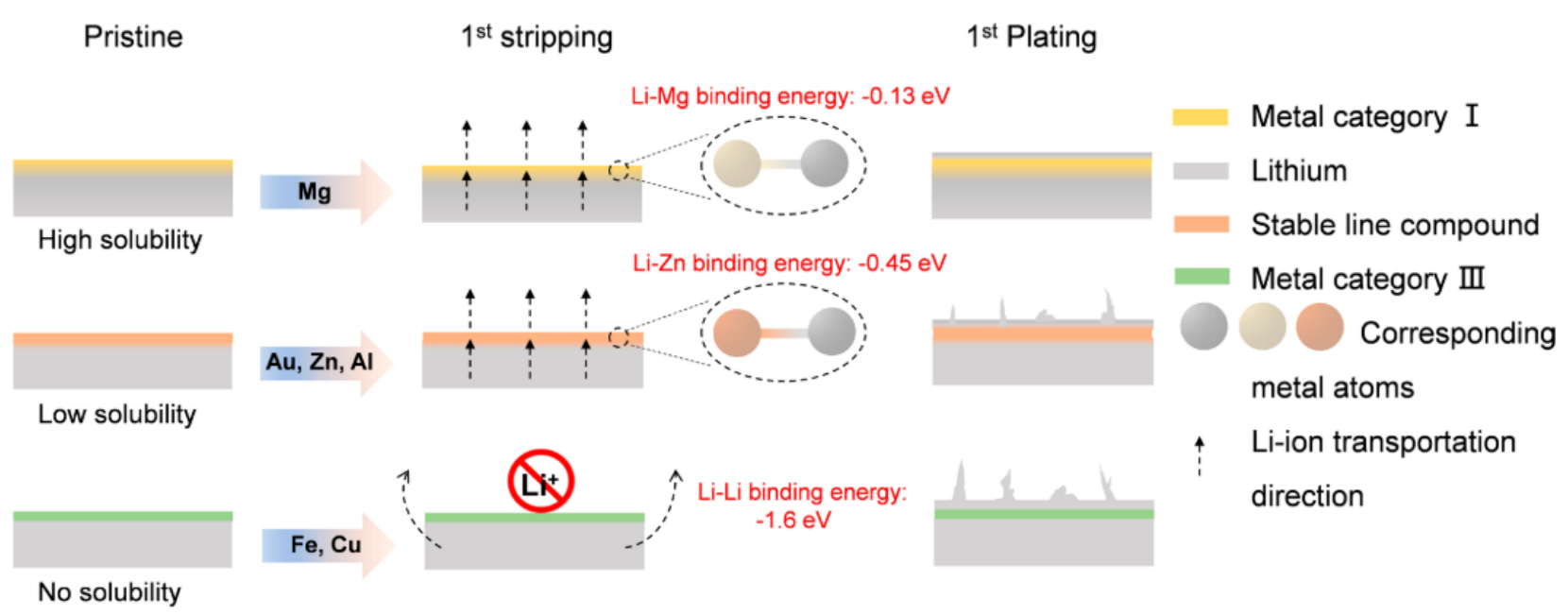

Figure 6. Protective mechanisms for Li plating/stripping depending on the nature of the metals solubility. Reproduced with permission from Ref [55]. Copyright 2020, American Chemical Society

The positive effect of the metal $M$ used for coating on alkali plating/stripping can also be related to the Young's modulus of the interface alloy(s). Indeed it was shown that the cycle life and capacity retention of alloys used as negative electrodes, especially in $\mathrm{Na}$-ion batteries for $\mathrm{M}=\mathrm{Sb}$ and $\mathrm{Sn}$, lies partially in the elastic softening of highly sodiated alloys and a high flexibility of $\mathrm{Na}-\mathrm{X}$ bonds, producing a system with enhanced ability to absorb and mitigate the strong volume changes occurring upon alkali insertion/deinsertion. ${ }^{[85,86]}$ The improved polarization stability of protected electrodes compared to bare ones is partially due to the different SEI created upon cycling. Due to their high reactivity, and to the increasing surface of the metal electrode with the number of cycles, bare alkali metals lead to an excess reduction of the electrolyte that tends to form a thick SEI composed with inorganic and organic species. ${ }^{[44,64]}$ However, as shown above in Equation 1, the strategy of chemical halide reduction leads to the formation of alkali alloys on the electrode surface along with the creation of an inorganic by-product. In most cases, the reactants used in the coating solution are metal halides such as $\mathrm{MCl}_{\mathrm{x}}$ or $\mathrm{MF}_{\mathrm{x}}$, which produce the precipitation of alkali or alkaline-earth chlorides or fluorides usually insoluble in the electrolyte. The electronic insulating properties of these compounds as well as their high elastic modulus (70,32 and $37.6 \mathrm{GPa}$ for $\mathrm{LiF}$, $\mathrm{LiCl}$ and $\mathrm{NaCl}$, respectively) 
hamper the electrolyte decomposition and the resulting SEI is thinner and less fragile than without the coating. ${ }^{[44,47,61]}$ Such a thin and flexible SEI formed thanks to the presence of the protective layer can then withstand the volume change of the metallic electrode occurring during the plating/stripping and remain stable in the long-term. ${ }^{[58,64]}$

Moreover, the presence of conducting compounds (alloys) and insulators (by-products) induces a potential gradient through the layer, allowing the diffusion across the film of alkali cations that eventually plate underneath the protective layer. ${ }^{[44,61]}$ This process was highlighted by XPS by Liang et al. (Fig. 7): the In $3 d$ XPS spectrum of an In-protected Li electrode after Li plating and before Ar sputtering (Fig.7 b, top) shows no signal. At the same time, different lithium components appear in the Li 1s one, meaning that the uppermost layer of the electrode is covered by a relatively thick passivation film composed of different organic and inorganic lithium species. However, deeper within the electrode (after 5 min and 10 min of sputtering with $\mathrm{Ar}$ ), the predominant signal becomes that of $\mathrm{Li}_{13} \mathrm{In}_{3}$ accompanied by those of In and $\mathrm{LiCl}$, whereas no organic lithium species are observed. Since the thickness of the layer removed by Ar sputtering is lower than the thickness of the Li normally plated with $2 \mathrm{~mA} \mathrm{~h} \mathrm{~cm}{ }^{-2}$, they assumed that the lithium goes through the layer and only a thin deposited Li layer remains on the surface. ${ }^{[44]}$ Similarly, Lv et al. used SEMEDX to show that the Mg plates below the Sn-protective layer (Fig. $7 \mathrm{c}$ ). ${ }^{[61]}$

a)

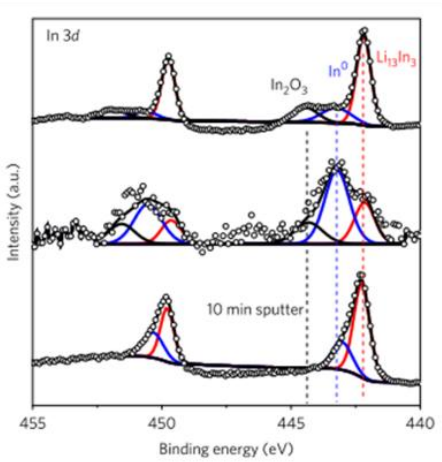

C)
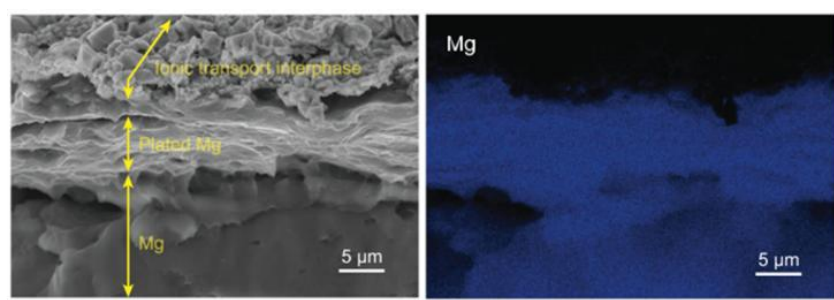

b)

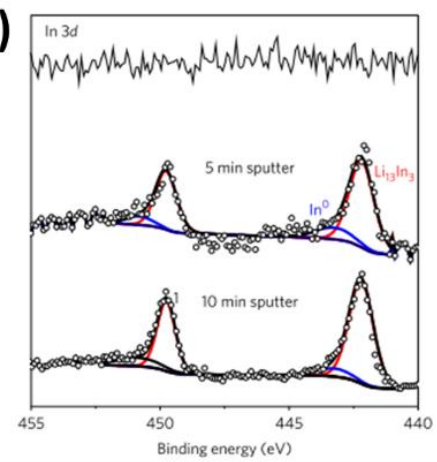

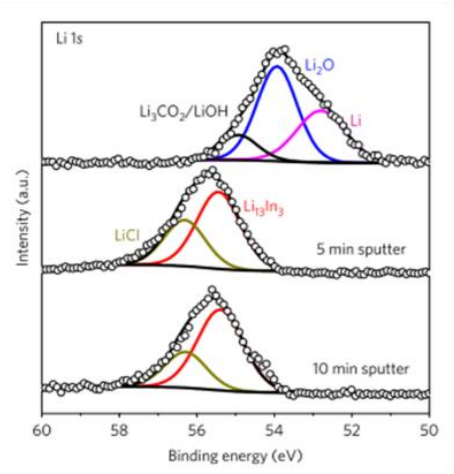

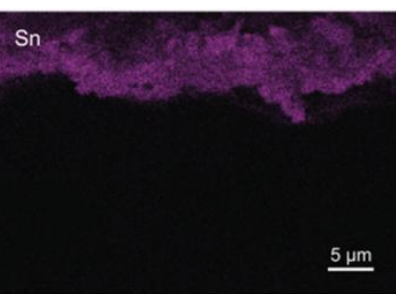

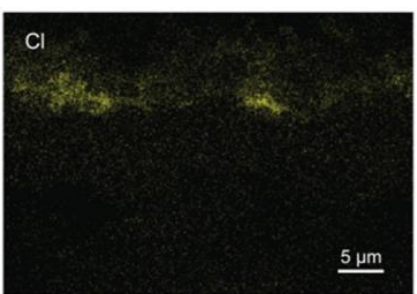

Figure 7. XPS analysis of the In-protected Li metal electrode: (a) In 3d spectra before Li plating and (b) In 3d

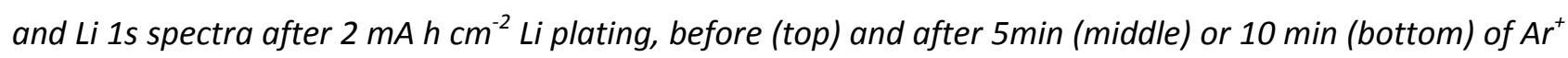

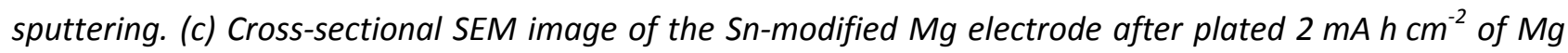
and the corresponding EDX mapping of $\mathrm{Mg}$, Sn and Cl. Reproduced with permission from Refs. [44] and [61]. Copyright 2017 Springer Nature and 2019 Oxford University Press. 
In other studies, the choice of more complex and certainly more expensive salts containing TFSI, TFS or $\mathrm{SO}_{3} \mathrm{CF}_{3}$ anions was motivated by the use of the as-obtained by-product ( $\mathrm{Na}\left(\mathrm{SO}_{3} \mathrm{CF}_{3}\right)$ for example) as soluble salt in battery electrolytes. ${ }^{[45,47,51,59]}$ Based on the thickness of the layer reported by Ma et al. and considering that the whole layer is composed of bismuth, the amount of $\mathrm{Na}\left(\mathrm{SO}_{3} \mathrm{CF}_{3}\right)$ generated is close to $10^{-4}$ mol. ${ }^{[59]}$ This is of same order of magnitude of the amount of salt in $100 \mu \mathrm{L}$ of the $1 \mathrm{M}$ concentrated electrolyte used in this reference. Consequently, using this kind of salts directly in the electrolyte instead of halide salts could theoretically allow the alloy formation on the alkali metal surface while the by-product participates to the overall ionic conductivity of the electrolyte.

Summarizing, an alloy-protected metal anode can provide satisfying performance only via the interplay of the following complementary features:

- a metal $\mathrm{M}$ highly soluble in alkali will allow an easy stripping from the surface layer, a good diffusion from the metal electrode to reform the surface alloy, and furthermore will lead to lower overpotentials.

- an alkali alloy with low elastic modulus will allow mitigating the volume changes during cycling and thus enhancing the lifespan of the electrode.

- a "good" SEI, highly dependent of the previously mentioned parameters, will be able to withstand the volume change of the electrode and increase its long-term cycling.

- the use of salts in the coating solution leading to electronic insulating properties and high elastic modulus, will improve the SEI (which will be thinner but more robust). Moreover, mixed with conducting alloys, it will induce a potential gradient through the layer, driving alkali cations plating underneath the protective layer. 


\begin{tabular}{|c|c|c|c|c|c|c|c|c|}
\hline \multirow[t]{2}{*}{ Electrode } & \multirow[t]{2}{*}{ Coating } & \multirow[t]{2}{*}{ Electrolyte } & \multirow{2}{*}{$\begin{array}{c}\text { Current } \\
\text { conditions } \\
\left(\mathrm{mA} \mathrm{cm}^{-2}\right) \text { per } \\
\text { hour }\end{array}$} & \multicolumn{2}{|c|}{$\begin{array}{l}\text { Polarization }(\mathrm{V}) \text { at the } \\
\text { beginning/end of cycling }\end{array}$} & \multicolumn{2}{|c|}{ Cycle life } & \multirow[t]{2}{*}{ Ref } \\
\hline & & & & bare & coated & Bare & coated & \\
\hline \multirow[t]{23}{*}{$\mathrm{Li}$} & $\mathrm{Li}_{13} \ln _{3}$ & \multirow[t]{4}{*}{ LiTFSI (1 M) + DOL/DME } & \multirow[t]{4}{*}{2 for $1 \mathrm{~h}$} & \multirow[t]{4}{*}{$\sim 0.1 / 0.2$} & $0.05 / 0.1$ & \multirow[t]{4}{*}{$200 \mathrm{~h}$} & $>1200 \mathrm{~h}$ & \multirow[t]{4}{*}{ [44] } \\
\hline & LiZn & & & & $0.05 / 0.1$ & & $>1000 \mathrm{~h}$ & \\
\hline & $\mathrm{Li}_{3} \mathrm{As}$ & & & & $0.05 / 0.18$ & & $1400 \mathrm{~h}$ & \\
\hline & $\mathrm{Li}_{3} \mathrm{Bi}$ & & & & $0.05 / 0.2$ & & $1200 \mathrm{~h}$ & \\
\hline & \multirow[t]{2}{*}{ In-based } & LiTFSI (1 M) + PC & 1 for $1 \mathrm{~h}$ & $\sim 0.2 / 0.3$ & $\sim 0.2 / 0.1$ & $<100 \mathrm{~h}$ & $200 \mathrm{~h}$ & \multirow[t]{2}{*}[45]{} \\
\hline & & $\mathrm{LiPF}_{6}(1 \mathrm{M})+\mathrm{EC} / \mathrm{DMC}$ & 3 for $1 \mathrm{~h}$ & $\sim 0.1 / 0.4$ & $\sim 0.1 / 0.2$ & $120 \mathrm{~h}$ & $200 \mathrm{~h}$ & \\
\hline & \multirow[t]{2}{*}{$\mathrm{Li}_{\mathrm{x}} \ln \mathrm{n}$} & $\mathrm{LiPF}_{6}(1 \mathrm{M})+\mathrm{EC} / \mathrm{DMC}$ & \multirow[t]{2}{*}{1 for $1 \mathrm{~h}$} & $\sim 0.1 / 0.4$ & $\sim 0.1 / 0.2$ & $300 \mathrm{~h}$ & $400 \mathrm{~h}$ & \multirow[t]{2}{*}[46]{} \\
\hline & & LiTFSI (1 M) + DOL/DME & & $\sim 0.2 / 0.3$ & $\sim 0.025 / 0.1$ & $<800 \mathrm{~h}$ & $1000 \mathrm{~h}$ & \\
\hline & $\mathrm{Li}_{x} \mathrm{Al}$ & $\begin{array}{c}\text { LiTFSI }(1 \mathrm{M})+\mathrm{DOL} / \mathrm{DME}+ \\
2 \mathrm{wt} \% \mathrm{LiNO}_{3}\end{array}$ & 1 for $1 \mathrm{~h}$ & $0.08 / 0.02$ & $\sim 0.08 / 0.02$ & $500 \mathrm{~h}$ & $1000 \mathrm{~h}$ & [49] \\
\hline & Li-Zn & $\mathrm{LiPF}_{6}(1 \mathrm{M})+\mathrm{EC} / \mathrm{DEC} / \mathrm{DMC}$ & 1 for $1 \mathrm{~h}$ & $\sim 0.2 / 0.4$ & $0.05 / 0.1$ & $300 \mathrm{~h}$ & $400 \mathrm{~h}$ & {$[50]$} \\
\hline & $\mathrm{LiZn}$ & LiTFSI (1 M) + DOL/DME & 2 for $1 \mathrm{~h}$ & $0.1 / 0.15$ & $\sim 0.1 / 0.1$ & $200 \mathrm{~h}$ & $500 \mathrm{~h}$ & {$[51]$} \\
\hline & $\mathrm{Sb}$ & LiTFSI (1 M) + DOL/DME & 0.5 for $2 \mathrm{~h}$ & $0.1 / 0.2$ & $0.05 / 0.05$ & $520 \mathrm{~h}$ & $>1200 \mathrm{~h}$ & {$[52]$} \\
\hline & $\mathrm{Li}_{5} \mathrm{Sn}_{2}$ & $\mathrm{LiPF}_{6}(1 \mathrm{M})+\mathrm{EC} / \mathrm{DEC}$ & 1 for $1 \mathrm{~h}$ & $\sim 0.2 / 1.2$ & $\sim 0.1 / 0.2$ & $250 \mathrm{~h}$ & $>800 \mathrm{~h}$ & {$[53]$} \\
\hline & LiAl & $\mathrm{LiPF}_{6}(1 \mathrm{M})+\mathrm{EC} / \mathrm{DEC}$ & 0.5 for $2 \mathrm{~h}$ & $0.08 / 0.125$ & $0.07 / 0.16$ & $620 \mathrm{~h}$ & $1600 \mathrm{~h}$ & [54] \\
\hline & Li-Mg & \multirow[t]{6}{*}{$\mathrm{LiPF}_{6}(1 \mathrm{M})+\mathrm{EC} / \mathrm{DEC}$} & \multirow[t]{6}{*}{2 for $1 \mathrm{~h}$} & \multirow[t]{6}{*}{$0.14 / 0.3$} & $0.06 / 0.06$ & \multirow[t]{6}{*}{$90 \mathrm{~h}$} & $200 \mathrm{~h}$ & \multirow[t]{6}{*}[55]{} \\
\hline & Li-Au & & & & $0.085 / 0.4$ & & $180 \mathrm{~h}$ & \\
\hline & Li-Al & & & & $0.067 / 0.2$ & & $140 \mathrm{~h}$ & \\
\hline & $\mathrm{Li}-\mathrm{Zn}$ & & & & $0.084 / 0.5$ & & $100 \mathrm{~h}$ & \\
\hline & Li-Fe & & & & $0.090 / 0.5$ & & $120 \mathrm{~h}$ & \\
\hline & $\mathrm{Li}-\mathrm{Cu}$ & & & & $0.095 / 0.5$ & & $50 \mathrm{~h}$ & \\
\hline & $\mathrm{Ag}_{\mathrm{x}} \mathrm{Li}_{\mathrm{y}}$ & $\begin{array}{c}\text { LiTFSI (1 M) + DOL/DME + } \\
1 \mathrm{wt} \% \mathrm{LiNO}_{3} \\
\end{array}$ & 2.5 for $1 \mathrm{~h}$ & $0.04 / 0.1$ & $0.04 / 0.05$ & $375 \mathrm{~h}$ & $>800 \mathrm{~h}$ & {$[56]$} \\
\hline & Ge-based & LiTFSI (1 M) + TEGDME & 3 for $20 \mathrm{~min}$ & $\sim 0.15 / 1$ & $\sim 0.1 / 0.1$ & $<125 \mathrm{~h}$ & $>300 \mathrm{~h}$ & [65] \\
\hline & $\mathrm{Bi}$ & $\mathrm{LiPF}_{6}(1 \mathrm{M})+\mathrm{EC} / \mathrm{DMC}$ & 1 for $1 \mathrm{~h}$ & $0.12 / 0.38$ & $0.1 / 0.078$ & $150 \mathrm{~h}$ & $300 \mathrm{~h}$ & {$[66]$} \\
\hline
\end{tabular}

Page 15 


\begin{tabular}{|c|c|c|c|c|c|c|c|c|}
\hline & In-based & $\mathrm{LiPF}_{6}(1 \mathrm{M})+\mathrm{EC} / \mathrm{DMC}$ & 0.5 for $1 \mathrm{~h}$ & $0.05 / 0.1$ & $0.025 / 0.05$ & $540 \mathrm{~h}$ & $>540 \mathrm{~h}$ & [68] \\
\hline & Si-based & LiTFSI (1 M) + DOL/DME & 1 for $1 \mathrm{~h}$ & $0.02 / 0.13$ & $0.04 / 0.014$ & $<100 \mathrm{~h}$ & $500 \mathrm{~h}$ & {$[69]$} \\
\hline & $\mathrm{Hg}$ & LiTFSI (1 M) + DOL/DME & 4 for $1 \mathrm{~h}$ & 0.045 / 1 & $0.045 / 0.1$ & $300 \mathrm{~h}$ & $>900 \mathrm{~h}$ & [70] \\
\hline & \multirow[t]{3}{*}{$\mathrm{Li}_{2} \mathrm{Ga}$} & $\mathrm{LiPF}_{6}(1 \mathrm{M})+\mathrm{EC} / \mathrm{DEC}$ & \multirow[t]{3}{*}{2 for $30 \mathrm{~min}$} & $\sim 0.25 / 0.3$ & $\sim 0.05 / 0.3$ & $100 \mathrm{~h}$ & $>250 \mathrm{~h}$ & \multirow[t]{3}{*}[57]{} \\
\hline & & LiTFSI (1 M) + DOL & & $\sim 0.05 / 0.18$ & $\sim 0.05 / 0.04$ & $<300 \mathrm{~h}$ & $1800 \mathrm{~h}$ & \\
\hline & & LiTFSI (1 M) + DOL/DME & & $\sim 0.1 / 0.04$ & $\sim 0.02 / 0.03$ & $200 \mathrm{~h}$ & $>500 \mathrm{~h}$ & \\
\hline & \multirow[t]{2}{*}{$\mathrm{Li}_{5} \mathrm{Sn}_{2}$} & $\mathrm{LiPF}_{6}(1 \mathrm{M})+\mathrm{EC} / \mathrm{DEC}$ & \multirow[t]{2}{*}{1 for $1 \mathrm{~h}$} & $\sim 0.03 / 0.6$ & $\sim 0.03 / 0.015$ & $400 \mathrm{~h}$ & $800 \mathrm{~h}$ & \multirow[t]{2}{*}{67} \\
\hline & & $\begin{array}{c}\text { LiTFSI }(1 \mathrm{M})+\mathrm{DOL} / \mathrm{DME}+ \\
1 \mathrm{wt} \% \mathrm{LiNO}_{3} \\
\end{array}$ & & $\sim 0.05 / 0.03$ & $\sim 0.03 / 0.02$ & $900 \mathrm{~h}$ & $900 \mathrm{~h}$ & \\
\hline & \multirow[t]{2}{*}{ Sn-based } & $\begin{array}{c}\mathrm{LiPF}_{6}(1 \mathrm{M})+\mathrm{EC} / \mathrm{DMC}+ \\
10 \mathrm{v} \% \mathrm{FEC}+1 \mathrm{v} \% \mathrm{VC} \\
\end{array}$ & 3 for $1 \mathrm{~h}$ & $0.4 / 0.3$ & $\sim 0.3 / 0.2$ & $55 \mathrm{~h}$ & $>500 \mathrm{~h}$ & \multirow[t]{2}{*}[47]{} \\
\hline \multirow[t]{7}{*}{$\mathrm{Na}$} & & NaPF6 (1 M) + EC/PC & 0.25 for $1 \mathrm{~h}$ & $\sim 0.1 / 3$ & $\sim 0.2 / 0.6$ & $250 \mathrm{~h}$ & $1700 \mathrm{~h}$ & \\
\hline & Sn-based & $\mathrm{NaClO}_{4}(1 \mathrm{M})+\mathrm{EC} / \mathrm{PC}$ & 0.5 for $2 \mathrm{~h}$ & $\sim 0.1 / 0.8$ & $\sim 0.3 / 0.1$ & $<400 \mathrm{~h}$ & $>500 h$ & [58] \\
\hline & $\mathrm{Na} / \mathrm{Bi}$ & $\mathrm{NaSO}_{3} \mathrm{CF}_{3}(1 \mathrm{M})+\mathrm{G} 2$ & 0.5 for $2 \mathrm{~h}$ & $0.025 /-$ & $0.025 / 0.025$ & $250 \mathrm{~h}$ & $1000 \mathrm{~h}$ & {$[59]$} \\
\hline & $\mathrm{Na}_{1.17} \mathrm{Sn}_{2}$ & $\mathrm{NaSO}_{3} \mathrm{CF}_{3}(1 \mathrm{M})+\mathrm{G} 2$ & 2 for $30 \mathrm{~min}$ & $\sim 0.1 / 0.3$ & $\sim 0.1 / 0.2$ & $<150 \mathrm{~h}$ & $650 \mathrm{~h}$ & [64] \\
\hline & $\mathrm{Hg}$ & $\mathrm{NaClO}_{4}(1 \mathrm{M})+\mathrm{EC} / \mathrm{PC}$ & 2 for $1 \mathrm{~h}$ & - & $0.01 / 0.01$ & $250 \mathrm{~h}$ & $1400 \mathrm{~h}$ & [72] \\
\hline & $\begin{array}{c}\mathrm{SnCl}_{2} \\
\text { coating }\end{array}$ & \multirow[t]{2}{*}{$\mathrm{NaPF}_{6}(1 \mathrm{M})+$ Diglyme } & \multirow[t]{2}{*}{2 for $30 \mathrm{~min}$} & \multirow[t]{2}{*}{$\sim 0.05 / 0.2$} & $\sim 0.025 / 0.5$ & \multirow[t]{2}{*}{$1000 \mathrm{~h}$} & $1900 \mathrm{~h}$ & \multirow[t]{2}{*}[60]{} \\
\hline & $\begin{array}{c}\mathrm{SnCl}_{4} \\
\text { coating }\end{array}$ & & & & $\sim 0.025 / 0.08$ & & $4500 \mathrm{~h}$ & \\
\hline $\mathrm{K}$ & $\mathrm{Hg}$ & $\mathrm{KFSI}+\mathrm{DME}$ & 0.2 for $1 \mathrm{~h}$ & $0.2 /-$ & $\sim 0.18 / 0.18$ & $<50 \mathrm{~h}$ & $600 \mathrm{~h}$ & [71] \\
\hline \multirow[t]{3}{*}{$\mathrm{Mg}$} & Sn-based & $\mathrm{Mg}(\mathrm{TFSI})_{2}(0.5 \mathrm{M})+\mathrm{DME}$ & 0.01 for $30 \mathrm{~min}$ & $1.5 / 5$ & $0.5 / 0.5$ & $450 \mathrm{~h}$ & $>600 \mathrm{~h}$ & [61] \\
\hline & $\mathrm{Ge}$ & $\mathrm{Mg}(\mathrm{TFSI})_{2}(0.5 \mathrm{M})+\mathrm{DME}$ & 0.02 for $15 \mathrm{~min}$ & $2.5 / 2$ & $\sim 0.2 / 0.3$ & $563 \mathrm{~h}$ & $1000 \mathrm{~h}$ & {$[62]$} \\
\hline & $\mathrm{Bi}$ & $\mathrm{Mg}(\mathrm{TFSI})_{2}(0.5 \mathrm{M})+\mathrm{DME}$ & 0.5 for $15 \mathrm{~min}$ & $2 / 2.5$ & $0.27 / 0.27$ & $38 \mathrm{~h}$ & $>150 \mathrm{~h}$ & {$[63]$} \\
\hline
\end{tabular}

Table 3: Long-term plating/stripping performance for bare alkali metals and coated electrodes 


\section{Coating influence on cell performance}

Once the positive influence of the coating on metal plating/stripping has been verified, the next logical step of implementing the as-protected metal electrode in a full cell. By choosing a common, possibly standardized positive electrode and comparing the cycling behavior with protected and unprotected metal anodes, it should then be easy to evaluate the influence of the coating by following the electrochemical performance. For evaluating the behavior of Li protected electrodes, Nazar and coworkers used $\mathrm{Li}_{4} \mathrm{Ti}_{5} \mathrm{O}_{12}$ (LTO) as the positive electrode material (average working potential of $1.55 \mathrm{~V} \mathrm{vs} \mathrm{Li}^{+} / \mathrm{Li}$ ) and showed that the full cells exhibit a stable coulombic efficiency (CE) for more than 1000 cycles at a $5 \mathrm{C}$ rate for the different coatings whereas with a bare lithium anode the CE drops drastically after 300 or 600 cycles depending on the electrolyte. ${ }^{[4,46]}$ Full cells with Lithium Nickel Manganese Cobalt Oxide (NMC) positive electrode also present enhanced long-term stability with In-protected Li electrodes and a CE of $98 \%$ for at least 250 cycles. ${ }^{[45]}$ Generally, the main issue with Li-metal/NMC batteries is the steady polarization increase leading to poor capacity retention. However, in the studies of Pathak et al., and Xu et al., ${ }^{[53,54]}$ the replacement of bare Li with $\mathrm{Sn}$ - or Al-protected $\mathrm{Li}$ anodes mitigates this increase in polarization and improves the capacity retention of the NMC full cell. This is related to a more stable lithium plating/stripping process with the coated electrode than with bare Li. Zheng et al. investigated the effect of the addition of a $\mathrm{SnCl}_{2}$ to the electrolyte in a $\mathrm{Na} / \mathrm{Na}_{3} \mathrm{~V}_{2}\left(\mathrm{PO}_{4}\right)_{3}$ (NVP) full cells. ${ }^{[58]}$ The $\mathrm{SnCl}_{2}$ additive favors $\mathrm{Na}^{+}$transport through the interface, leading to a lower polarization upon cycling and, compared with unprotected $\mathrm{Na}$ electrodes (control electrolyte), a higher capacity retention ( $87 \%$ vs. $75 \%$ for bare $\mathrm{Na}$ ) for 250 cycles (Fig. 8b). The alloy coating exhibits great advantages also for Mg batteries, which suffer from severe passivation of the $\mathrm{Mg}$ electrode leading to rapid capacity fading upon cycling. Lv et al. showed that a full cell built with a Sn-modified $\mathrm{Mg}$ anode and a $\mathrm{TiS}_{2}$ cathode delivers a steady capacity of $200 \mathrm{~mA} \mathrm{~h} \mathrm{~g}^{-1}$ after 25 cycles at $10 \mathrm{~mA} \mathrm{~g}^{-1}$ whereas the capacity of an unprotected-Mg/TiS cell rapidly fades below $50 \mathrm{~mA} \mathrm{~h} \mathrm{~g}^{-1}$ after 5 cycles (Fig. 8c).

Aside from insertion-type cathode materials, coating the metal negative electrode can also be of interest for metal/sulfur batteries. Despite their low potential, sulfur-based positive electrodes theoretically offer high capacities and could lead to high energy-density batteries. However, the major hurdles of metal/sulfur batteries is the well-known polysulfide shuttle effect. In short, intermediate polysulfide species formed during the electrochemical reduction of sulfur dissolve in the electrolyte and then shuttle to the negative electrode. This process induces a progressive capacity fading which prevents so far the development of such systems. ${ }^{[87-90]}$ Chen et al. show that a lithiophilic Sb-based interfacial protection on lithium electrode improves the cycling of lithium/sulfur cells. Using a LiTFSI/(DOL+DME) electrolyte and commercial carbon nanotubes (CNTs) as the sulfur 
host, they observed lower potential hysteresis, higher discharge capacity and a better capacity retention ( $90 \%$ after 50 cycles at $0.1 \mathrm{C}$, compared to $74 \%$ with an unprotected lithium electrode). ${ }^{[52]}$ The chemical evolution of the active species was followed during cycling by operando Raman spectroscopy. At the end of discharge, $\mathrm{Li}_{2} \mathrm{~S}_{4}$ and $\mathrm{Li}_{2} \mathrm{~S}_{6}$ were observed using a bare lithium electrode, whereas they were barely detected with Sb-protected lithium. In addition to decreasing the dendrite growth, the coating seems thus to effectively lower the shuttle effect. Similarly, Kumar and coworkers investigated $\mathrm{Na} / \mathrm{S}$ systems and reported an extended lifespan with sodium electrode treated with $\mathrm{SnCl}_{4}{ }^{[64]}$

a)
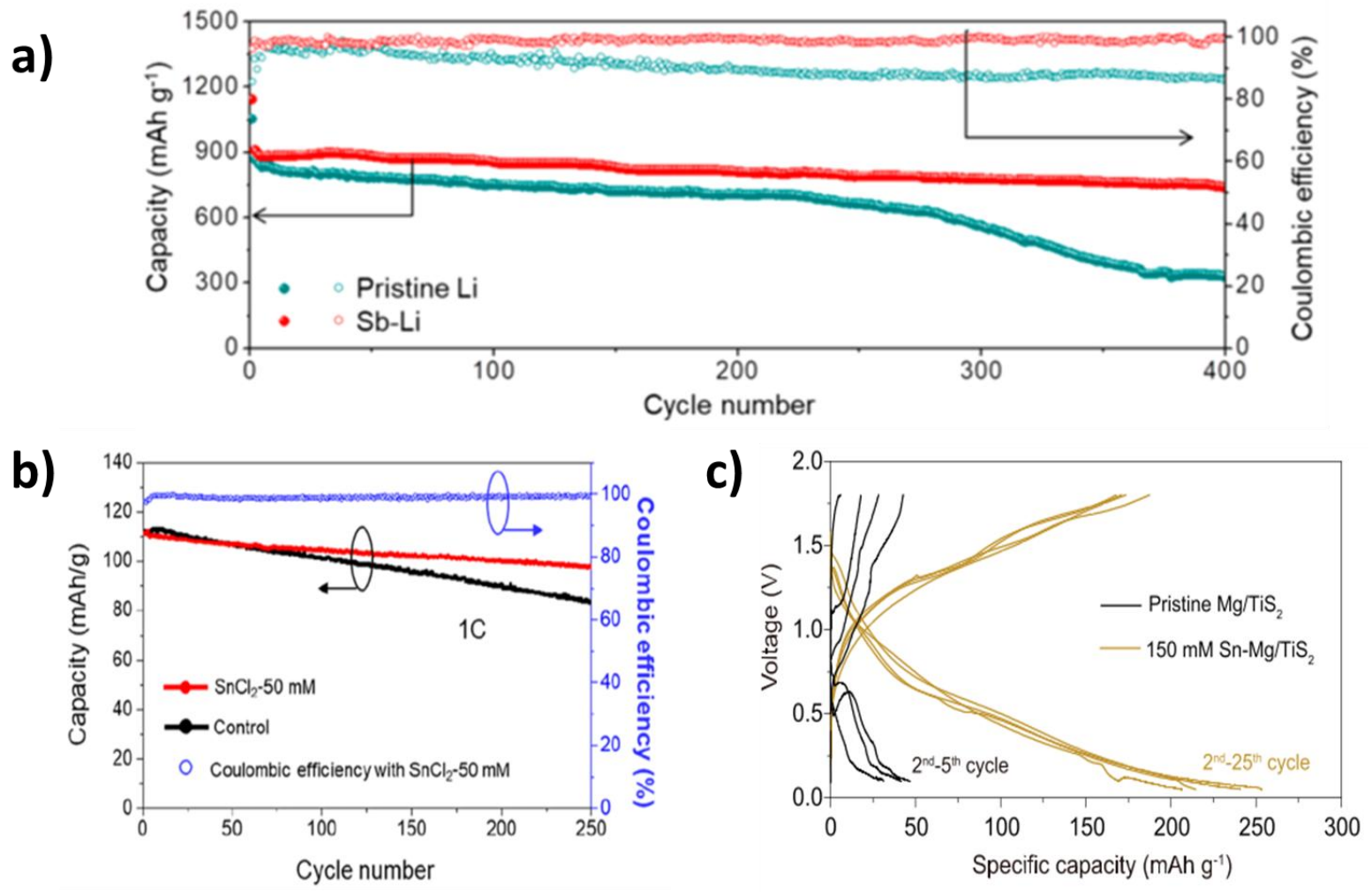

Figure 8. Comparison of full cells long-term performance between unprotected and protected metal electrode: (a) Li/S with a Sb-based protection, in LiTFSI (1M) + DOL/DME at 1C, (b) Na/NVP with Snbased protection, in $\mathrm{NaClO}_{4}(1 \mathrm{M})+E C / P C$ at $1 \mathrm{C}$ and (c) $\mathrm{Mg} / \mathrm{TiS}{ }_{2}$ with Sn-based protection in $\mathrm{Mg}(\mathrm{TFSI})_{2}$ $(0.5 \mathrm{M})+D M E$ at a current density of $10 \mathrm{~mA} / \mathrm{g}$. Adapted with permission from references [48], [58] and [61]. Copyright 2019 American Chemical Society, 2019 Oxford University Press and 2019 American Chemical Society, respectively.

It seems important to remind that lithium metal batteries have been so far prepared with an important excess of lithium at the negative electrode. Obviously, targeting high energy density systems requires the reduction of this nominal excess, but this is a challenging task as manufacturing thin layer of lithium is not an easy process. ${ }^{[91,92]}$ In the conditions of a perfectly balanced system, the thickness of the interfacial coating could overcome that of lithium, the coating material being the 
main electrochemically active component at the negative side. For example, in a theoretical Li/ $/ \mathrm{FeO}_{4}$ battery with $1 \mathrm{mg} \mathrm{cm}^{-2}$ at the positive side, the lithium layer thickness would be below $0.9 \mu \mathrm{m}$, which is significantly lower than the thicknesses reported in Tables 1 and 2. Consequently, it seems reasonable to claim that these coating strategies are of interest in the current configuration of lithium metal battery but could be questionable if very thin layer of lithium are one day really considered.

\section{Other directions for alloy-type coating}

\subsection{Improving metal stability}

As shown above, alloy-type materials could offer an efficient coating to protect lithium and other metal electrodes from dendritic growth. Besides that, alloy-type coatings can provide an enhanced stability toward various electrolytes or environments. In this regard, the case of $\mathrm{Mg}$ metal batteries is interesting. Indeed, when magnesium is immersed in a carbonate-based electrolyte, a thick and resistive passivation layer is created on the surface. ${ }^{[35]}$ Unlike lithium, in this particular case, magnesium ions cannot diffuse through this layer, and thus electrochemical plating/stripping is hampered. This is the reason why the development of $\mathrm{Mg}$ metal batteries is firstly driven by the design of electrolytes that are compatible with magnesium metal. ${ }^{[93]}$ However, an efficient coating might allow the use of classical electrolyte solvents such as carbonates. In this direction, Wang and coworkers recently designed an artificial conducting polymeric film made on thermal-cyclized polyacrylonitrile with magnesium triflate salt and reversible plating/stripping was possible during 1000 cycles with $\mathrm{Mg}(\mathrm{TFSI})_{2} / \mathrm{PC}$ electrolyte. ${ }^{[94]}$ Going back to alloy-type coatings, Xia and Luo recently reported a first attempt by dropping a $\mathrm{SnCl}_{2} /$ DME solution onto magnesium surface. ${ }^{[61]} \mathrm{A} 2 \mu \mathrm{m}$ thick composite layer containing $\mathrm{Sn}, \mathrm{Mg}_{2} \mathrm{Sn}$ and chlorides was generated, and the as-coated anode showed extended cycling performance with a simple $\mathrm{Mg}(\mathrm{TFSI})_{2} / \mathrm{DME}$ electrolyte. Similar results were later obtained by designing tridimensional $\mathrm{Mg}_{3} \mathrm{Bi}_{2}$ scaffolds by treating magnesium foils with $\mathrm{BiCl}_{3} / \mathrm{DME}$ solutions. ${ }^{[95]}$ The next logical step would be to evaluate protected magnesium in classical solvents such as organic carbonates to check their viability and possibly pave the way to high energy density Mg metal batteries.

Metal electrodes in metal-air batteries suffer from dendrite growth but also from morphological change ("infinite" volume change), corrosion, side reactions $\left(\mathrm{O}_{2}\right.$ crossover effect) and surface passivation. Besides other strategies such as designing 3D hosts, coating the surface of the metal electrode is a way to achieve improved performance. To the best of our knowledge, the work of Liao and coworkers has pioneered this field by proposing the alloy-type protection of lithium for metal/air 
applications. ${ }^{[65]}$ In their study, lithium electrodes protected by immersion in $\mathrm{GeCl}_{4} / \mathrm{THF}$ steam enable to reach an enhanced stability against water and consequently a better cycle life in $\mathrm{Li} / \mathrm{O}_{2}$ cells running in moist conditions.

a)
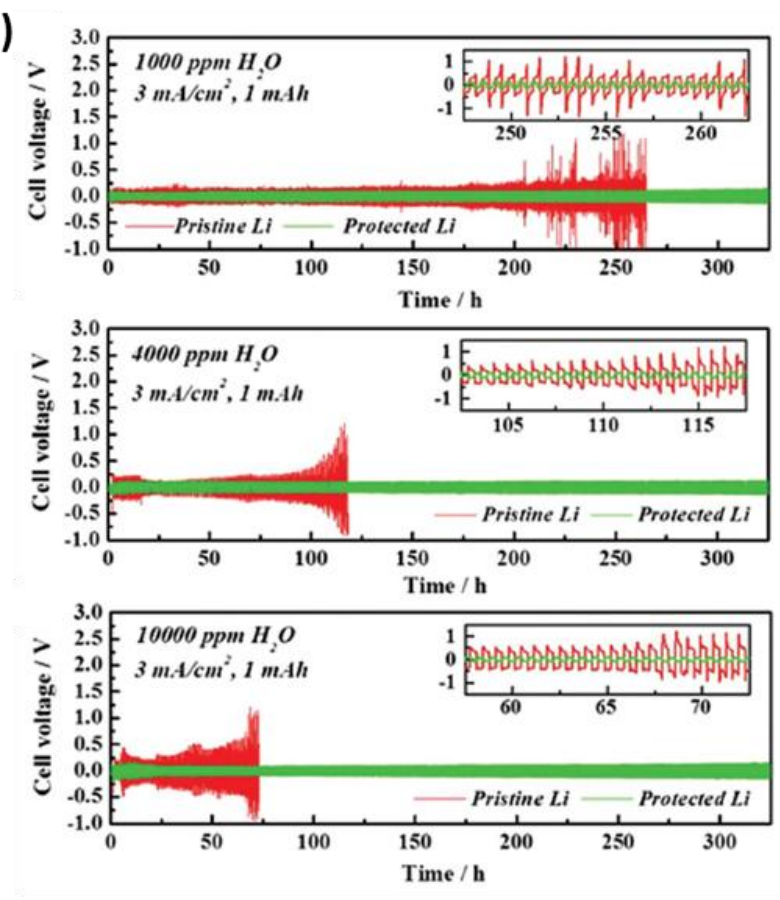

b)
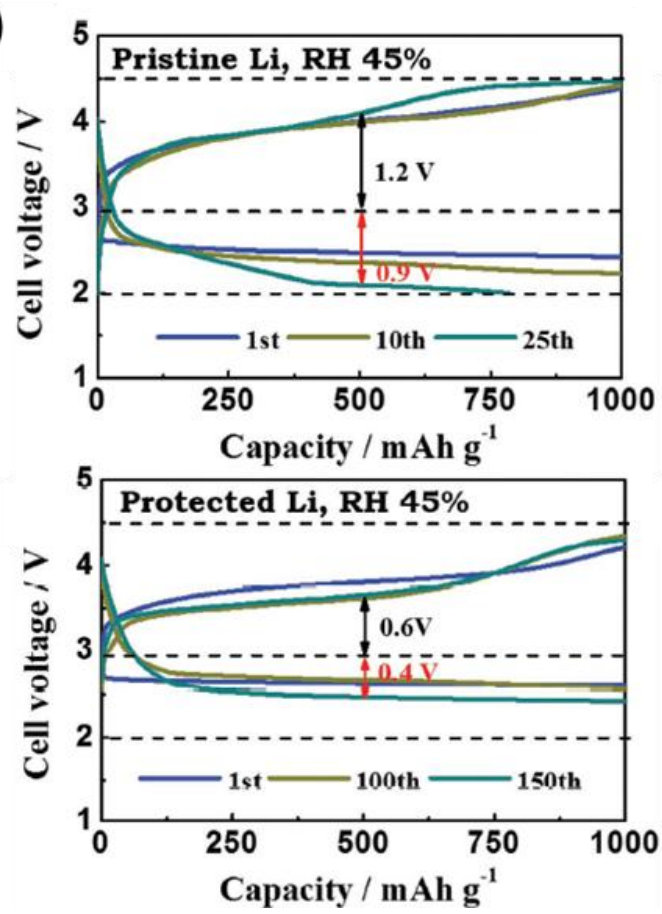

Figure 9: Electrochemical behavior of lithium electrode in humid atmosphere during in symmetric cells (a) or in $\mathrm{Li} / \mathrm{O}_{2}$ cells (b). In both cases, electrodes protected by a preliminary treatment with $\mathrm{GeCl}_{4} / \mathrm{THF}$ steam exhibit better stability and lifetime, and less polarization. Adapted with permission from Ref. [65], Copyright, 2018, Wiley.

\subsection{Toward in situ coating through electrolyte additives}

At a first glance, metal surface coating by a solution treatment is already widely performed in industrial plants. Therefore, the protocols described in Table 1 could be readily transferable to industrial production. Even if chemical plating occurs instantaneously, the implementation of a preliminary task of pretreatment of the metal anode should still be considered, adding extra costs to the whole industrial process. It seems then reasonable to prefer a coating that can be generated during battery assembly by including an appropriate precursor of the metal to be reduced as an additive of the electrolyte. In their pioneering work, Choudhury et al. opened the way for this in situ method by adding $\operatorname{In}(\mathrm{TFSI})_{3}(12 \mathrm{mM})$ to a classical LiPF 6 /EC:DMC (1M) electrolyte. ${ }^{[45]}$ Interestingly, the indium salt reduction produces LiTFSI, another common salt for LIB electrolyte that remains in the electrolyte and participate to further electrochemically cycling. Nazar and coworkers also underlined the interest of including indium halides as an additive to the electrolyte. ${ }^{[46]}$ Furthermore, the excess 
of metal salt that is not reduced during the initial chemical plating could act as a self-healing agent during further electrochemical cycling, enabling the formation of new alloy coating. Despite these noteworthy advantages, surprisingly most of the subsequent works did not include a metal salt additive to the electrolyte and preferred to follow a 2-step method with a preliminary treatment on the electrode before the battery assembly.

\section{Conclusion and perspectives}

Coatings made with alkali metal alloys seem to be an efficient way to protect metal electrodes from dendrite growth and then to increase the cycle life of alkali metal batteries. In order to efficiently improve the performance, such coated layers should have (i) a good ionic conductivity to facilitate the ion transport, (ii) a high adhesion to the electrode to resist to the volume change, (iii) a high elastic modulus hindering the growth of dendrites and (iv) a low electrolyte permeability to limit the electrolyte reduction occurring at the metallic electrode. The chemical reduction of a metal salt in solution in contact with the metallic electrode appears to be the most promising technique for an efficient coating. The wide choice of salt and solvents allows tuning the properties of the obtained coating through the careful control of their concentration and of the reaction time. The nature of $\mathrm{M}$ and $\mathrm{X}$ has also a high influence on the mechanic properties (Young's modulus) and consequently on the lifespan of the protected electrodes in metal batteries. This coating approach seems reasonably adapted to industrialization and marketing if practical applications are further considered.

After the pioneering reports of the research groups of Nazar and Archer, in the last few years a large variety of coating solutions has been proposed. Recently, coating strategies enabling also the protection of other metallic electrodes such as sodium, potassium and magnesium have been reported. In order to find whether they are viable, these proof-of-concept coating strategies should now be extensively benchmarked to clearly determine the most appropriate and advantageous one by systematically comparing the nature of both the salt and the solvent, as well as the salt concentration. Other practical parameters such as costs and sustainability need to be further considered for obtaining a marketable solution. In this industrial application perspective, the in situ formation of coatings obtained via the addition of an appropriate metal precursor to the electrolyte appears to be a practical way to efficiently protect alkali metal surfaces, and thus obtain the corresponding protected metal anode in a simpler and more viable fashion.

\section{Acknowledgements:}


The authors gratefully acknowledge financial support from the French National Research Agency (project MISTRALE, ANR-19-CE05-0013, and Labex STORE-EX, ANR-10-LABX-76-01).

\section{References}

[1] M. S. WHITTINGHAM, Science (80-. ). 1976, 192, 1126-1127.

[2] D. A. Winn, J. M. Shemilt, B. C. H. Steele, Mater. Res. Bull. 1976, 11, 559-566.

[3] H. Zhang, C. Li, G. G. Eshetu, S. Laruelle, S. Grugeon, K. Zaghib, C. Julien, A. Mauger, D. Guyomard, T. Rojo, et al., Angew. Chemie 2020, 132, 542-546.

[4] R. Yazami, P. Touzain, J. Power Sources 1983, 9, 365-371.

[5] A. Mauger, C. M. Julien, J. B. Goodenough, K. Zaghib, J. Electrochem. Soc. 2020, 167, 070507.

[6] K. Mizushima, P. Jones, P. Wiseman, J. B. Goodenough, Solid State Ionics 1981, 3-4, 171-174.

[7] H. Zhang, C. Li, G. G. Eshetu, S. Laruelle, S. Grugeon, K. Zaghib, C. Julien, A. Mauger, D. Guyomard, T. Rojo, et al., Angew. Chem. Int. Ed. 2020, 59, 534-538.

[8] N. W. Li, Y. Shi, Y. X. Yin, X. X. Zeng, J. Y. Li, C. J. Li, L. J. Wan, R. Wen, Y. G. Guo, Angew. Chemie - Int. Ed. 2018, 57, 1505-1509.

[9] R. Xu, X. Q. Zhang, X. B. Cheng, H. J. Peng, C. Z. Zhao, C. Yan, J. Q. Huang, Adv. Funct. Mater. 2018, 28, 1-7.

[10] C. Fu, C. Battaglia, ACS Appl. Mater. Interfaces 2020, 12, 41620-41626.

[11] Q. Chen, Z. Hou, Z. Sun, Y. Pu, Y. Jiang, Y. Zhao, H. He, T. Zhang, L. Huang, ACS Appl. Energy Mater. 2020, 3, 2900-2906.

[12] S. Wang, Y. Jie, Z. Sun, W. Cai, Y. Chen, F. Huang, Y. Liu, X. Li, R. Du, R. Cao, et al., ACS Appl. Energy Mater. 2020, 3, 8688-8694.

[13] A. C. Kozen, C. F. Lin, A. J. Pearse, M. A. Schroeder, X. Han, L. Hu, S. B. Lee, G. W. Rubloff, M. Noked, ACS Nano 2015, 9, 5884-5892.

[14] P. K. Alaboina, S. Rodrigues, M. Rottmayer, S.-J. Cho, ACS Appl. Mater. Interfaces 2018, 10, 32801-32808.

[15] Y. Zhao, L. V. Goncharova, A. Lushington, Q. Sun, H. Yadegari, B. Wang, W. Xiao, R. Li, X. Sun, Adv. Mater. 2017, 29, 1606663.

[16] W. Luo, C. F. Lin, O. Zhao, M. Noked, Y. Zhang, G. W. Rubloff, L. Hu, Adv. Energy Mater. 2017, 7, 1601526 .

[17] L. Liu, Y. X. Yin, J. Y. Li, Y. G. Guo, L. J. Wan, Chem. Commun. 2018, 54, 5330-5333. 
[18] N. W. Li, Y. X. Yin, C. P. Yang, Y. G. Guo, Adv. Mater. 2016, 28, 1853-1858.

[19] G. Wang, X. Xiong, D. Xie, X. Fu, Z. Lin, C. Yang, K. Zhang, M. Liu, ACS Appl. Mater. Interfaces 2019, 11, 4962-4968.

[20] S. Li, Q. Liu, X. Wang, Q. Wu, L. Fan, W. Zhang, Z. Shen, L. Wang, M. Ling, Y. Lu, ACS Mater. Lett. 2020, 2, 1-8.

[21] M. Wu, Z. Wen, Y. Liu, X. Wang, L. Huang, J. Power Sources 2011, 196, 8091-8097.

[22] D. Larcher, S. D. Beattie, M. Morcrette, K. Edström, J.-C. Jumas, J.-M. Tarascon, J. Mater. Chem. 2007, 17, 3759-3772.

[23] M. N. Obrovac, V. L. Chevrier, Chem. Rev. 2014, 114, 11444-11502.

[24] W.-J. Zhang, J. Power Sources 2011, 196, 13-24.

[25] C.-M. Park, J.-H. Kim, H. Kim, H.-J. Sohn, Chem. Soc. Rev. 2010, 39, 3115-3141.

[26] J. Hassoun, B. Scrosati, J. Electrochem. Soc. 2015, 162, A2582-A2588.

[27] D.-L. Cheng, L.-C. Yang, M. Zhu, Rare Met. 2018, 37, 167-180.

[28] L. Li, Y. Zheng, S. Zhang, J. Yang, Z. Shao, Z. Guo, Energy Environ. Sci. 2018, 11, 2310-2340.

[29] C. Bommier, X. Ji, Isr. J. Chem. 2015, 55, 486-507.

[30] M. Lao, Y. Zhang, W. Luo, Q. Yan, W. Sun, S. X. Dou, Adv. Mater. 2017, 29, 1700622.

[31] D. Li, Y. Yuan, J. Liu, M. Fichtner, F. Pan, J. Magnes. Alloy. 2020, DOI:10.1016/j.jma.2020.09.017.

[32] A. Darwiche, M. T. Sougrati, B. Fraisse, L. Stievano, L. Monconduit, Electrochem. Commun. 2013, 32, 18-21.

[33] A. Darwiche, C. Marino, M. T. Sougrati, B. Fraisse, L. Stievano, L. Monconduit, J. Am. Chem. Soc. 2012, 134, 20805-20811.

[34] V. Gabaudan, L. Monconduit, L. Stievano, R. Berthelot, Front. Energy Res. 2019, 7, 46.

[35] J. Niu, Z. Zhang, D. Aurbach, Adv. Energy Mater. 2020, 10, 2000697.

[36] L. C. Loaiza, L. Monconduit, V. Seznec, Small 2020, 16, 1905260.

[37] B. Liang, Y. Liu, Y. Xu, J. Power Sources 2014, 267, 469-490.

[38] X. Zuo, J. Zhu, P. Müller-Buschbaum, Y.-J. Cheng, Nano Energy 2017, 31, 113-143.

[39] K. Feng, M. Li, W. Liu, A. G. Kashkooli, X. Xiao, M. Cai, Z. Chen, Small 2018, 14, 1702737.

[40] D. Mazouzi, Z. Karkar, C. Reale Hernandez, P. Jimenez Manero, D. Guyomard, L. Roué, B. Lestriez, J. Power Sources 2015, 280, 533-549. 
[41] B. D. Assresahegn, D. Bélanger, ChemSusChem 2017, 10, 4080-4089.

[42] X. Su, Q. Wu, J. Li, X. Xiao, A. Lott, W. Lu, B. W. Sheldon, J. Wu, Adv. Energy Mater. 2014, 4, 1300882 .

[43] J.-M. Tarascon, Nat. Chem. 2010, 2, 510-510.

[44] X. Liang, Q. Pang, I. R. Kochetkov, M. S. Sempere, H. Huang, X. Sun, L. F. Nazar, Nat. Energy 2017, 6, 17119.

[45] S. Choudhury, Z. Tu, S. Stalin, D. Vu, K. Fawole, D. Gunceler, R. Sundararaman, L. A. Archer, Angew. Chemie Int. Ed. 2017, 56, 13070-13077.

[46] Q. Pang, X. Liang, I. R. Kochetkov, P. Hartmann, L. F. Nazar, Angew. Chemie Int. Ed. 2018, 57, 9795-9798.

[47] Z. Tu, S. Choudhury, M. J. Zachman, S. Wei, K. Zhang, L. F. Kourkoutis, L. A. Archer, Nat. Energy 2018, 3, 310-316.

[48] T. Chen, W. Kong, P. Zhao, H. Lin, Y. Hu, R. Chen, W. Yan, Z. Jin, Chem. Mater. 2019, 31, 75657573.

[49] G. Hou, C. Ci, H. Guo, X. Zhang, Q. Sun, J. Cheng, D. Salpekar, Q. Ai, L. Chen, A. B. Puthirath, et al., Chem. Eng. J. 2020, 391, 123542.

[50] F. Li, Y. H. Tan, Y. C. Yin, T. W. Zhang, L. L. Lu, Y. H. Song, T. Tian, B. Shen, Z. X. Zhu, H. Bin Yao, Chem. Sci. 2019, 10, 9735-9739.

[51] Y. Lin, Z. Wen, C. Yang, P. Zhang, J. Zhao, Electrochem. commun. 2019, 108, 106565.

[52] T. Chen, W. Kong, P. Zhao, H. Lin, Y. Hu, R. Chen, W. Yan, Chem. Mater. 2019, 31, 7565-7574.

[53] R. Pathak, K. Chen, A. Gurung, K. M. Reza, B. Bahrami, J. Pokharel, A. Baniya, W. He, F. Wu, Y. Zhou, et al., Nat. Commun. 2020, 11, 1-10.

[54] B. Xu, Z. Liu, J. Li, X. Huang, B. Qie, T. Gong, L. Tan, X. Yang, D. Paley, M. Dontigny, et al., Nano Energy 2020, 67, DOI 10.1016/j.nanoen.2019.104242.

[55] Y. Xu, S. Zhao, G. Zhou, W. Chen, F. Zhou, Z. Rong, Y. Wu, J. Li, J. Guo, Y. Zhang, ACS Appl. Energy Mater. 2020, 3, 2278-2284.

[56] H. Wang, M. Liu, X. Wang, W. Zhang, Y. Che, L. Chen, Y. Wu, W. Li, J. Mater. Chem. A 2020, 8, 12045-12054.

[57] S. Liu, Q. Zhao, X. Zhang, J. Liu, L. Dai, L. Wang, J. Luo, J. Mater. Chem. A 2020, 8, 1741517419.

[58] X. Zheng, H. Fu, C. Hu, H. Xu, Y. Huang, J. Wen, H. Sun, W. Luo, Y. Huang, J. Phys. Chem. Lett. 
$2019,10,707-714$.

[59] M. Ma, Y. Lu, Z. Yan, J. Chen, Batter. Supercaps 2019, 2, 663-667.

[60] Q. Chen, H. He, Z. Hou, W. Zhuang, T. Zhang, Z. Sun, L. Huang, J. Mater. Chem. A 2020, 8, 16232-16237.

[61] R. Lv, X. Guan, J. Zhang, Y. Xia, J. Luo, Natl. Sci. Rev. 2019, DOI 10.1093/nsr/nwz157.

[62] J. Zhang, X. Guan, R. Lv, D. Wang, P. Liu, J. Luo, Energy Storage Mater. 2020, 26, 408-413.

[63] B. Wan, H. Dou, X. Zhao, J. Wang, W. Zhao, M. Guo, Y. Zhang, J. Li, Z.-F. Ma, X. Yang, ACS Appl. Mater. Interfaces 2020, DOI 10.1021/acsami.0c07213.

[64] V. Kumar, A. Y. S. Eng, Y. Wang, D. T. Nguyen, M. F. Ng, Z. W. Seh, Energy Storage Mater. 2020, 29, 1-8.

[65] K. Liao, S. Wu, X. Mu, Q. Lu, M. Han, P. He, Z. Shao, H. Zhou, Adv. Mater. 2018, 30, DOI 10.1002/adma.201705711.

[66] T. Chen, F. Meng, Z. Zhang, J. Liang, Y. Hu, W. Kong, X. L. Zhang, Z. Jin, Nano Energy 2020, 76, 105068.

[67] S. Xia, X. Zhang, C. Liang, Y. Yu, W. Liu, Energy Storage Mater. 2020, 24, 329-335.

[68] B. Sun, J. Lang, K. Liu, N. Hussain, M. Fang, H. Wu, Chem. Commun. 2019, 55, 1592-1595.

[69] T. Xu, P. Gao, P. Li, K. Xia, N. Han, J. Deng, Y. Li, J. Lu, Adv. Energy Mater. 2020, 10, DOI 10.1002/aenm.201902343.

[70] G. He, Q. Li, Y. Shen, Y. Ding, Angew. Chemie - Int. Ed. 2019, 58, 18466-18470.

[71] Q. Yang, Y. Ding, G. He, Chem. Commun. 2020, 56, 3512-3515.

[72] Q. Zhang, M. Hu, J. He, X. Liu, G. He, Y. Ding, J. Mater. Chem. A 2020, 6822-6827.

[73] Q. Pang, X. Liang, A. Shyamsunder, L. F. Nazar, Joule 2017, 1, 871-886.

[74] J.-N. Chazalviel, Phys. Rev. A 1990, 42, 7355-7367.

[75] C. Brissot, M. Rosso, J.-N. Chazalviel, S. Lascaud, J. Power Sources 1999, 81-82, 925-929.

[76] P. Bai, J. Li, F. R. Brushett, M. Z. Bazant, Energy Environ. Sci. 2016, 9, 3221-3229.

[77] K. N. Wood, E. Kazyak, A. F. Chadwick, K. H. Chen, J. G. Zhang, K. Thornton, N. P. Dasgupta, ACS Cent. Sci. 2016, 2, 790-801.

[78] B. Lee, E. Paek, D. Mitlin, S. W. Lee, Chem. Rev. 2019, DOI 10.1021/acs.chemrev.8b00642.

[79] B. Sun, P. Xiong, U. Maitra, D. Langsdorf, K. Yan, C. Wang, J. Janek, D. Schröder, G. Wang, Adv. Mater. 2019, DOI 10.1002/adma.201903891. 
[80] Y. Li, L. Zhang, S. Liu, X. Wang, D. Xie, X. Xia, C. Gu, J. Tu, Nano Energy 2019, 62, 367-375.

[81] M. S. Ding, T. Diemant, R. J. Behm, S. Passerini, G. A. Giffin, J. Electrochem. Soc. 2018, 165, A1983-A1990.

[82] R. Davidson, A. Verma, D. Santos, F. Hao, C. Fincher, S. Xiang, J. Van Buskirk, K. Xie, M. Pharr, P. P. Mukherjee, et al., ACS Energy Lett. 2019, 4, 375-376.

[83] S. Choudhury, Z. Tu, S. Stalin, D. Vu, K. Fawole, D. Gunceler, R. Sundararaman, L. A. Archer, Angew. Chemie Int. Ed. 2017, 56, 13070-13077.

[84] K. Yan, Z. Lu, H.-W. Lee, F. Xiong, P.-C. Hsu, Y. Li, J. Zhao, S. Chu, Y. Cui, Nat. Energy 2016, 1, 16010

[85] M. Mortazavi, J. Deng, V. B. Shenoy, N. V. Medhekar, J. Power Sources 2013, 225, 207-214.

[86] P. K. Allan, J. M. Griffin, A. Darwiche, O. J. Borkiewicz, K. M. Wiaderek, K. W. Chapman, A. J. Morris, P. J. Chupas, L. Monconduit, C. P. Grey, J. Am. Chem. Soc. 2016, 138, 2352-2365.

[87] M. Wild, L. O’Neill, T. Zhang, R. Purkayastha, G. Minton, M. Marinescu, G. J. Offer, Energy Environ. Sci. 2015, 8, 3477-3494.

[88] A. Manthiram, Y. Fu, S.-H. Chung, C. Zu, Y.-S. Su, Chem. Rev. 2014, 114, 11751-11787.

[89] Y. He, Z. Chang, S. Wu, H. Zhou, J. Mater. Chem. A 2018, 6, 6155-6182.

[90] X. Yu, A. Manthiram, Adv. Funct. Mater. 2020, 30, 2004084.

[91] A. Varzi, K. Thanner, R. Scipioni, D. Di Lecce, J. Hassoun, S. Dörfler, H. Altheus, S. Kaskel, C. Prehal, S. A. Freunberger, J. Power Sources 2020, 480, 228803.

[92] J. Schnell, T. Günther, T. Knoche, C. Vieider, L. Köhler, A. Just, M. Keller, S. Passerini, G. Reinhart, J. Power Sources 2018, 382, 160-175.

[93] Z. Lu, A. Schechter, M. Moshkovich, D. Aurbach, J. Electroanal. Chem. 1999, 466, 203-217.

[94] S. B. Son, T. Gao, S. P. Harvey, K. X. Steirer, A. Stokes, A. Norman, C. Wang, A. Cresce, K. Xu, C. Ban, Nat. Chem. 2018, 10, 532-539.

[95] B. Wan, H. Dou, X. Zhao, J. Wang, W. Zhao, M. Guo, Y. Zhang, J. Li, Z.-F. Ma, X. Yang, ACS Appl. Mater. Interfaces 2020, 12, 28298-28305. 